\title{
A new genus, Zhurbenkoa, and a novel nutritional mode revealed in the family Malmideaceae (Lecanoromycetes, Ascomycota)
}

\section{Adam Flakus, Javier Etayo, Sergio Pérez-Ortega, Martin Kukwa, Zdeněk Palice \& Pamela Rodriguez-Flakus}

To cite this article: Adam Flakus, Javier Etayo, Sergio Pérez-Ortega, Martin Kukwa, Zdeněk Palice \& Pamela Rodriguez-Flakus (2019) A new genus, Zhurbenkoa, and a novel nutritional mode revealed in the family Malmideaceae (Lecanoromycetes, Ascomycota), Mycologia, 111:4, 593-611, DOI: $10.1080 / 00275514.2019 .1603500$

To link to this article: https://doi.org/10.1080/00275514.2019.1603500

\section{Published online: 28 May 2019.}

\section{Submit your article to this journal $\widetilde{ }$}

Џll Article views: 235

Q View related articles

View Crossmark data $₫$

Citing articles: 4 View citing articles $₫$ 


\title{
A new genus, Zhurbenkoa, and a novel nutritional mode revealed in the family Malmideaceae (Lecanoromycetes, Ascomycota)
}

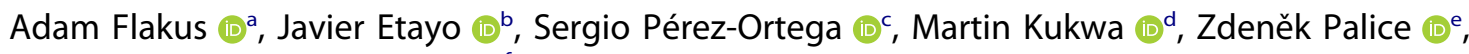 \\ and Pamela Rodriguez-Flakus (it ${ }^{f}$
}

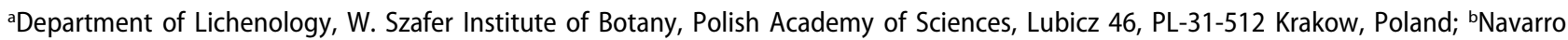
Villoslada 16, $3^{\circ}$ dcha., E-31003 Pamplona, Navarra, Spain; 'Real Jardín Botánico, Plaza de Murillo 2, 28014 Madrid, Spain; ${ }^{d}$ Department of Plant Taxonomy and Nature Conservation, Faculty of Biology, University of Gdańsk, Wita Stwosza 59, PL-80-308 Gdańsk, Poland; elnstitute of Botany, Czech Academy of Sciences, CZ-25243 Průhonice, Czech Republic; ' Laboratory of Molecular Analyses, W. Szafer Institute of Botany, Polish Academy of Sciences, Lubicz 46, PL-31512 Krakow, Poland

\begin{abstract}
Lichen-inhabiting fungi are highly specialized mycoparasites, commensals or rarely saprotrophs, that are common components of almost every ecosystem, where they develop obligate associations with lichens. Their relevance, however, contrasts with the relatively small number of these fungi described so far. Recent estimates and ongoing studies indicate that a significant fraction of their diversity remains undiscovered and may be expected in tropical regions, in particular in hyperdiverse fog-exposed montane forests. Here, we introduce the new genus Zhurbenkoa, from South America and Europe, for three lichenicolous fungi growing on thalli of the widespread lichen genus Cladonia (Lecanorales). Phylogenetic analyses based on combined sequence data of $\mathrm{mt}$ and nuc rDNA obtained from Andean populations (Bolivia) placed Zhurbenkoa as a member of Malmideaceae, a recently introduced family of lichen-forming fungi in the class Lecanoromycetes. Zhurbenkoa is closely related to the genera Savoronala and Sprucidea. The new genus is characterized by the development of grayish brown to almost black apothecia lacking an evident margin, an epihymenium interspersed with crystals (often seen as pruina), a strongly conglutinated hymenium made of noncapitate and sparsely branched paraphyses, a colorless exciple composed of radially arranged hyphae, a Lecanora/Micarea-like ascus type, and aseptate or 1-septate ellipsoidal colorless ascospores. Zhurbenkoa includes two Neotropical ( $Z$. cladoniarum, Z. latispora) and one widespread (Z. epicladonia) species. The lichenicolous trophic mode is documented for the first time in the Malmideaceae, which until now included only lichen-forming associations between fungi and green algae.
\end{abstract}

ARTICLE HISTORY

Received 2 December 2018

Accepted 2 April 2019

\section{KEY WORDS}

Arthonia epicladonia;

lichenicolous fungi;

Neotropics; Pezizomycotina;

phylogenetics; systematics; 4 new taxa

\section{INTRODUCTION}

About 2300 lichenicolous species are described worldwide, although recent estimates suggest that only a small part of their diversity is known (Hawksworth 2001; Lawrey and Diederich 2003; Diederich et al. 2018). Tropical ecosystems harbor a significant fraction of the known mycobiota (e.g., Hawksworth 1991, 1993, 2012), including the highest number of lichens-the hosts of lichenicolous fungi. This contrasts with the relatively small number of lichen-inhabiting species described from tropical regions (e.g., Diederich 1997; Etayo 2002, 2010, 2017). Therefore, one can hypothesize that the vast part of the missing diversity of licheninhabiting fungi is hidden in tropical lichen communities. Our recent observations in the Bolivian Andes, along with results of several other investigations in tropical regions, confirm that assumption (e.g., Hawksworth and Esslinger 1993; Diederich 1997; Etayo 2002, 2017; Flakus and Kukwa
2012; Diederich et al. 2014; Etayo et al. 2013, 2015, 2018; Flakus et al. 2014; Farkas and Flakus 2016; Suija et al. 2018). In particular, fog-exposed forests at high elevations are extremely diverse and rich in undescribed diversity of the lichen-inhabiting fungi (Diederich 1997; Flakus et al. 2016).

Most lichen-inhabiting fungi are considered obligate mycoparasites and commensals associated with lichens or to a lesser extent saprotrophs (Rambold and Triebel 1992; Hawksworth 2003; Lawrey and Diederich 2003). The trophic modes and the interactions with lichen symbionts vary among these fungi (de los Ríos et al. 2002). Although most lichenicolous species colonize the mycobiont, some species such as Zwackhiomyces coepulonus (Collemopsidiales, Dothideomycetes) or the recently described genus Austrostigmidium (Capnodiales, Dothideomycetes) associate with the photobiont (de los Ríos et al. 2002; Pérez-Ortega et al. 2015). 
Lichenicolous fungi are not monophyletic and are distributed across more than 50 different orders (Diederich et al. 2018). Most known lichenicolous fungi are Ascomycetes. Their phylogenetic relationships and evolutionary histories are only known for sparsely sampled groups, mainly of lichenicolous basidiomycetes (Sikaroodi et al. 2001; Lawrey et al. 2007, 2016; Millanes et al. 2011; Liu et al. 2016) or selected genera of Ascomycetes, including Abrothallales (Pérez-Ortega et al. 2014; Suija et al. 2015a), Asterinales (Ertz and Diederich 2015), Asterotexiales (Ertz et al. 2016), Arthoniales (Frisch et al. 2014), Capnodiales (Ruibal et al. 2011; Muggia et al. 2016), Chaetothyriales (Diederich et al. 2013; Muggia et al. 2015, 2016), Helotiales (Etayo et al. 2015; Suija et al. 2015b), Lecanoromycetes (Pino-Bodas et al. 2017), Lichenostigmatales (Ertz et al. 2014), Pleosporales (Lawrey et al. 2012; Trakunyingcharoen et al. 2014; Ertz et al. 2015; Muggia et al. 2016), and Trypetheliales (Ertz et al. 2015). This state of knowledge is mostly a consequence of the difficult access to fresh material from less-explored ecosystems and of rare lichenicolous species, as well as technical difficulties in obtaining axenic cultures, particularly when they grow biotrophically on their hosts.

Malmideaceae (Lecanoromycetes) was recently introduced to accommodate tropical, corticolous, lichen-forming fungi in the genus Malmidea, described for the former Lecidea piperis and Lecanora granifera groups (Kalb et al. 2011). Later studies added other tropical genera such as the peculiar genus Savoronala from Madagascar, which produces unique conidia that each include a single algal cell (Ertz et al. 2013), and the recently described genera Kalbionora from Thailand, Vietnam, and Australia (Sodamuk et al. 2017) and Sprucidea from Brazil (Cáceres et al. 2017). Lately, the temperate sporodochial genus Cheiromycina was shown to fall within Malmideaceae (Muggia et al. 2017). Additional members of the family include poorly known temperate-boreal taxa currently classified in Lecidea sensu lato (s.l.), which warrant recognitions as a separate genus. The placement in Malmideaceae was confirmed for two of them based on molecular data: the saxicolous 'Lecidea' cyrtidia and the epixylic 'L.' plebeja (Ertz et al. 2013). Several additional poorly known lecideoid lichens, mainly boreal taxa, which are morphologically close to 'L.' plebeja (e.g., 'Lecidea' malmeana complex or 'Lecidea' consimilis) likely belong here as well (Printzen 1995; Holien et al. 2016; Palice et al. 2018). It was hypothesized that also an enigmatic sporodochial genus Xyleborus, an Appalachian endemic, is a member of this family (Muggia et al. 2017). Malmideaceae as currently understood contains approximately 60 species of lichen-forming fungi (Kalb et al. 2011; Ertz et al. 2013; Miadlikowska et al. 2014; Breuss and Lücking 2015;
Cáceres et al. 2017; Muggia et al. 2017; Sodamuk et al. 2017), and the number will probably considerably arise in the near future.

The goal of this study was to assess the systematic position of two enigmatic lichenicolous fungi growing on Cladonia species, Lecidea epicladonia and Patellaria cladoniarum, and a putatively closely related undescribed species from Bolivia and Ecuador. Using DNA sequence data from nuc and mt rDNA, we inferred their systematic position as members of the Malmideaceae in the Lecanorales. This is the first time that the lichenicolous nutritional mode has been observed in this family.

\section{MATERIALS AND METHODS}

Taxon sampling and morphological studies.-Our study was based on material freshly collected by the authors and on historical herbarium specimens deposited at G, H, KRAM, LPB, UGDA, MA, PRA, and the private herbarium of J. Etayo (Pamplona). Morphology and the anatomy were examined using standard stereo- and compound microscopes (Nikon SMZ 800, Nikon Eclipse 80i DIC; Tokyo, Japan). Sections were prepared manually using a razor blade or a Thermo Fisher Scientific Microm HM430 (Waltham, Massachusetts, USA) freezing microtome combined with BFS-MP freezing stage and BFS-3MP controller. Sections and squash mounts were examined in tap water, $10 \% \mathrm{KOH}(\mathrm{K})$, or lactophenol cotton blue (LPCB; Sigma-Aldrich, catalog no. 61335100ML; St. Louis, Missouri, USA). All photomicrographs showing anatomical characters were made using transmitted differential interference contrast (DIC) microscopy. Amyloid reactions of anatomical structures were tested using Lugol's solution (I) (Sigma-Aldrich, catalog no. 62650-1L-F), without (I) or with (K/I) pretreatment with $10 \% \mathrm{KOH}$ solution. The solubility of crystals was tested using $\mathrm{K}$ and $50 \%$ nitric acid solution (N). All measurements were made in distilled water or LPCB. Ascospores measurements are presented as arithmetic mean $(\bar{x})$ and standard deviation $(s)$ (in parentheses), flanked by the minimum and maximum observed values, and the length/breadth ratio $(1 / b)$ is presented in the same way, followed by the number of measurements (n). Host lichen substances were investigated by thin-layer chromatography (TLC) in solvents $\mathrm{A}, \mathrm{B}^{\prime}$, and $\mathrm{C}$ following the methods by Culberson and Kristinsson (1970) and Orange et al. (2001).

DNA extraction, PCR amplification, and DNA sequencing.-Ascomata, which were stored together with host pieces frozen at $-20 \mathrm{C}$, were removed from 
the host thallus and carefully cleaned in double-distilled water $\left(\mathrm{dH}_{2} \mathrm{O}\right)$ on a microscope slide under sterile conditions to remove host tissues and other visible impurities using ultrathin tweezers and a razor blade. Genomic DNA was extracted from about five clean ascomata using the QIAamp DNA Investigator Kit (Qiagen, Hilden, Germany) following the manufacturer's instructions. We amplified both mtDNA small subunit DNA (mrSSU) using primers pair mrSSU1 and mrSSU3R (Zoller et al. 1999), and nuc rDNA large subunit (28S) with primers LROR, LR3, LR3R, and LR7 (Vilgalys and Hester 1990; Rehner and Samuels 1994). Polymerase chain reaction (PCR) reactions were performed in a volume of $25 \mu \mathrm{L}$ comprising $1 \mu \mathrm{L}$ of DNA template, $0.2 \mu \mathrm{L}$ of AmpliTaq 360 DNA polymerase (Applied Biosystems, California, USA), $2.5 \mu \mathrm{L}$ of $10 \times$ AmpliTaq 360 PCR Buffer, $2.5 \mu \mathrm{L}$ $25 \mathrm{mM} \mathrm{M} \mathrm{M}_{2} \mathrm{Cl}_{2}, 1 \mu \mathrm{L}$ of each primer $(10 \mu \mathrm{M}), 2 \mu \mathrm{L}$ GeneAmp dNTPs (10 mM; Applied Biosystems, California, USA), $0.2 \mu \mathrm{L}$ bovine serum albumin (BSA; New England Biolabs, Massachusetts, USA), and sterile distilled water was added to attain the final volume. PCR amplifications were performed using the thermocycling conditions of Rodriguez-Flakus and Printzen (2014). PCR products were visualized by running $3 \mu \mathrm{L}$ of the PCR product on $1 \%$ agarose gels. Purified amplicons (using the ExoSAP method [EURx, Gdańsk, Poland]) were labeled with BigDye Terminator 3.1 Cycle Sequencing Kit (Applied Biosystems, California, USA). The PCR products were sequenced using a 3100-Avant sequencer (Applied Biosystems) at the Laboratory of Molecular Analyses, W. Szafer Institute of Botany of Polish Academy of Sciences, Krakow. The newly generated $\mathrm{mtSSU}$ and nucLSU sequences were checked, assembled, and edited manually using Geneious Pro 8.0. (Biomatters, Auckland, New Zealand) and deposited in GenBank. Accession numbers are provided in TABLE 1.

\section{Phylogenetic analyses and taxon selection.-All} sequences generated were checked by BLAST (Altschul et al. 1990) to verify potential contaminations by an unrelated fungus. BLAST searches of both $28 \mathrm{~S}$ and mrSSU sequences from species of the new genus Zhurbenkoa revealed the highest similarity with Savoronala madagarcariensis (Malmideaceae, Lecanoromycetes). Therefore, we aligned Zhurbenkoa sequences with all available members of Malmidaceae and representatives of all other families of Lecanorales following the taxonomy of Miadlikowska et al. (2014).
Alignments were generated for each region using MAFFT (Katoh et al. 2005) as implemented on the GUIDANCE2 Web server (Penn et al. 2010). GUIDANCE2 assigns a confidence score to each ambiguous nucleotide site in the alignment and later remove regions of uncertain columns. We used the default cutoff score of 0.93 in all single gene alignments. The following analyses were performed in the CIPRES Scientific Gateway (http://www.phylo.org/portal2/) (Miller et al. 2010). PartitionFinder 2 (Lanfear et al. 2016) was used to select the best partition for our data and substitution models. A single substitution model was selected for each region (TIM+G for mrSSU, GTR $+\mathrm{I}+\mathrm{G}$ for 28S) under a greedy search algorithm and the Akaike information criterion (AIC) (Lanfear et al. 2012). Maximum likelihood (ML) analyses were carried out using a heuristic search as implemented in RAxMLHPC2 on XSEDE (Stamatakis 2006) applying the GTRGAMMAI model, and 100 bootstrap interactions on 1000 replicates to estimate branch support. Bayesian inference (BI) of the phylogenetic relationships was calculated using the Markov chain Monte Carlo (MCMC) approach as implemented in MrBayes 3.2.6 on XSEDE (Ronquist et al. 2012) using the partitions and substitution models obtained by PartitionFinder 2. Two independent parallel runs were started each with four incrementally heated (0.15) chains. This MCMC was allowed to run for 40 million generations, sampling every 1000th tree and discarding the first $50 \%$ of the samples tree as a burn-in factor. The analysis was stopped after 1 million generations when the standard deviation of split frequencies had dropped below 0.01 . Resulting ML and BI phylogenetic trees were visualized in TreeView (Page 1996). The tree was rooted by using Rusavskia elegans as the outgroup. Alignments were submitted to TreeBASE (study no. TB2 523582).

Statistical analysis. - Statistical species-level differences among the studied taxa in nonparametric multivariate analysis of variance (MANOVA) using ascospore length $(n=537)$ and ascospore breadth $(n=537)$ as dependent variables were calculated. Homogeneity and quality of the variance-covariance matrix were assessed using Box's $M$ and Levene's tests. The Wilks' lambda $(\Lambda)$ multivariate test was used to analyze the variance, and multiple comparisons of each dependent variable was performed by Tukey's honest significant differences (HSD) post hoc tests on ascospore sizes among species. We considered statistically significant differences among groups when $P$ $<0.05$. All analyses were conducted using the Statistical 
Table 1. Voucher data and GenBank accession numbers of sequences included in this study.

\begin{tabular}{|c|c|c|c|}
\hline \multirow[b]{2}{*}{ Taxon name } & \multirow[b]{2}{*}{ Source } & \multicolumn{2}{|c|}{ GenBank accession no. } \\
\hline & & nLSU rDNA & mtSSU rDNA \\
\hline Bacidia rosella & Sweden, Ekman 3117 (BG) & AY300829 & AY300877 \\
\hline Bacidia rubella & Poland, Kukwa 4598 (DUKE) & DQ986793 & DQ986808 \\
\hline Biatora vernalis & Norway, Klepsland JK09-L616 (0) & KF360446 & KF360418 \\
\hline Byssoloma leucoblepharum & Portugal, Ekman 3502 (BG) & AY756317 & AY567778 \\
\hline Calopadia foliicola & Costa Rica, Lücking 16011 (BG) & AY756318 & AY567782 \\
\hline Cheiromycina flabelliformis & Czech Republic, Palice 18257 (PRA) & MF431804 & MF431799 \\
\hline Cheiromycina petri & Czech Republic, Palice 17855 (PRA) & MF431805 & MF431800 \\
\hline Cheiromycina reimeri 1 & Poland, Kukwa 17422 (UGDA) & MF431807 & MF431803 \\
\hline Cheiromycina reimeri 2 & Poland, Kukwa 17681 (UGDA) & MF431806 & MF431802 \\
\hline Cladia moniliformis & Australia, Lumbsch et al. $19991 \mathrm{f}(\mathrm{F})$ & GQ500971 & GQ500934 \\
\hline Cladia retipora & Australia, Lumbsch et al. 19976a (F) & GQ500963 & GQ500931 \\
\hline Cladonia digitata & Sweden, Ekman 3424 (BG) & AY756319 & AY756366 \\
\hline Evernia prunastri & Belgium, Ertz 7596 (BR) & KJ766557 & KJ766389 \\
\hline Fellhanera bouteillei & Sweden, Ekman 3417 (BG) & AY756348 & AY567787 \\
\hline Fellhanera subtilis & Germany, Tønsberg 28199 (BG) & AY756321 & AY567786 \\
\hline Gypsoplaca macrophylla & Russia, Zhurbenko 92104 (UPS) & DQ899298 & DQ899299 \\
\hline Gypsoplaca sp. & USA, Spribille 38752 (herb. Spribille) & KP796393 & KP822511 \\
\hline Hypotrachyna caraccensis & Costa Rica, Lutzoni et al. s.n. (DUKE 47519) & DQ912336 & DQ912280 \\
\hline Kalbionora palaeotropica 1 & Thailand, Sodamuk s.n. (RAMK 24533) & KY926786 & N/A \\
\hline Kalbionora palaeotropica 2 & Viet Nam, Oh \& Thanh 130046a (F) & KY926787 & $\mathrm{N} / \mathrm{A}$ \\
\hline Lecanora campestris & Sweden, Arup L97370 (LD) & DQ787361 & DQ787362 \\
\hline Lecanora glabrata & Sweden, Fritz s.n. (LD)/Arup L011003 (LD) & DQ787359 & DQ787360 \\
\hline 'Lecidea' cyrtidia & USA, Lay 07-0076 (herb. Lay) & HQ660538 & HQ660563 \\
\hline Lecidea fuscoatra & Germany, Feige 6236 (DUKE) & DQ912332 & DQ912275 \\
\hline 'Lecidea' nylanderi & USA, Spribille 10020 (herb. Spribille) & HQ660545 & HQ660572 \\
\hline 'Lecidea' plebeja & Lithuania, Motiejūnaitè 7695 (FH) & HQ660549 & HQ660577 \\
\hline 'Lecidea' roseotincta & Norway, Tønsberg 34577 (herb. Schmull) & HQ660547 & HQ660575 \\
\hline Lecidea silacea & Finland, Stenroos 5682 (DUKE) & KJ766588 & DQ986878 \\
\hline Malmidea coralliformis & Thailand, Kalb et al. s.n. (herb. Kalb 37082) & N/A & HM447597 \\
\hline Malmidea eeuuae & Thailand, Kalb 36993 (herb. Kalb) & $\mathrm{N} / \mathrm{A}$ & HM447601 \\
\hline Malmidea floridensis & USA, May 3088 (herb. May) & HQ660540 & HQ660565 \\
\hline Micarea alabastrites & Norway, Andersen 17 (BG) & AY756327 & AY567764 \\
\hline Miriquidica complanata & Poland, Szczepańska 43 (herb. Szczepanska) & KP940386 & KP940385 \\
\hline Miriquidica garovaglii & Norway, Ekman s.n. (BG) & AY756357 & AY567711 \\
\hline Mycoblastus affinis & Canada, Scheidegger s.n. (Duke 47671); Sweden, Nordin 3216 (UPS) & KJ766601 & DQ899307 \\
\hline Parmotrema reticulatum & USA, Lutzoni \& Yahr s.n. (DUKE 5521) & DQ912339 & DQ912283 \\
\hline Peltigera degenii & Russia, Zavarzin s.n. (DUKE 47504) & AY584657 & AY584628 \\
\hline Protoblastenia calva & Croatia, Gueidan 659 (DUKE) & JQ301601 & DQ986904 \\
\hline Protoparmeliopsis achariana & Finland, Stjernberg s.n. (H) & KJ766633 & KJ766465 \\
\hline Protoparmeliopsis muralis & Germany, Schmull s.n. (herb. Schmull) & HQ660533 & HQ660556 \\
\hline Psilolechia leprosa & Norway, Tønsberg \& Botnen 27362 (BG) & AY756333 & AY567730 \\
\hline Psilolechia lucida & Finland, Haikonen $24578(\mathrm{H})$ & KJ766639 & KJ766472 \\
\hline Psora saviczii & Spain, Burgaz s.n. (AFTOL 4858) & KJ766641 & KJ766475 \\
\hline Psora testacea & Spain, Burgaz s.n. (AFTOL 4873) & KJ766642 & KJ766476 \\
\hline Ramalina complanata & USA, Hillis s.n. (DUKE 47924) & DQ973038 & DQ972986 \\
\hline Ramalina fastigiata & Hungary, Molnar \& Varga s.n. (DUKE 47751) & KJ766647 & KJ766481 \\
\hline Ramboldia brunneocarpa & Australia, Elix 36756 (F) & EU075520 & EU075528 \\
\hline Ramboldia elabens & Austria, Türk 39749 (H) & KJ766648 & KJ766482 \\
\hline Rusavskia elegans & Canada, Lutzoni \& Miądlikowska s.n. (DUKE 47558) & DQ912352 & DQ912304 \\
\hline Savoronala madagascariensis 1 & Madagascar, Serusiaux DNA537 (LG) & KC020142 & KC020144 \\
\hline Savoronala madagascariensis 2 & Madagascar, Serusiaux DNA538 (LG) & KC020143 & KC020145 \\
\hline Scoliciosporum intrusum & Norway, Ekman s.n. (BG) & AY756329 & AY567767 \\
\hline Scoliciosporum umbrinum & Norway, Ekman 3005 (BG) & AY300861 & AY567719 \\
\hline Scutula epiblastematica & Russia, Vershinina s.n. (LE 261003) & N/A & KY661688 \\
\hline Scutula tuberculosa & Sweden, Wedin 6356 (UPS) & N/A & AY567789 \\
\hline Scutula miliaris & Sweden, Wedin 6850 (UPS) & $\mathrm{N} / \mathrm{A}$ & AY567790 \\
\hline Solorina saccata & Romania, Pócs s.n. (DUKE 47739) & KJ766661 & KJ766494 \\
\hline Sphaerophorus fragilis & Canada, Lutzoni \& Miądlikowska s.n. (DUKE 47564) & DQ986805 & DQ986789 \\
\hline Sphaerophorus globosus & Canada, Scheidegger 45 (DUKE) & DQ986767 & DQ986866 \\
\hline Sprucidea gymnopiperis & Brazil, Cáceres 28322 (ISE) & MF093874 & MF093876 \\
\hline Sprucidea rubropenicillata & Brazil, Cáceres 28211 (ISE) & MF093875 & MF093877 \\
\hline Squamarina cartilaginea & Belgium, Ertz 7600 (BR); Spain, Burgaz s.n. (AFTOL 4850) & DQ986763 & KJ766496 \\
\hline Squamarina lentigera & Norway, Haugan \& Timdal 4801 (0) & AY756363 & AY756377 \\
\hline Stereocaulon intermedium & USA, Mc Cune 23483 (DUKE) & KJ766662 & KJ766497 \\
\hline Stereocaulon tomentosum & Sweden, Wedin 5089 (UPS) & AY340569 & AY340526 \\
\hline Tephromela atra & USA, Lutzoni s.n. (DUKE 47632) & DQ986764 & DQ986894 \\
\hline Toninia cinereovirens & Norway, Haugan \& Timdal 7953 (0) & AY756365 & AY567724 \\
\hline Xanthoparmelia conspersa & USA, Lutzoni s.n. (DUKE 5525) & AY584641 & AY584633 \\
\hline Xanthoria parietina & Sweden, Gaya et al. s.n. (BCN) & JQ301589 & JQ301530 \\
\hline Zhurbenkoa epicladonia 1 & Bolivia, Flakus 25212 (KRAM) & MK491328 & MK491331 \\
\hline Zhurbenkoa epicladonia 2 & Bolivia, Flakus 25624 (KRAM) & MK491329 & MK491332 \\
\hline Zhurbenkoa latispora & Bolivia, Flakus 25452 (KRAM) & MK491330 & MK491333 \\
\hline
\end{tabular}

Note. Newly generated sequences are marked in bold. 
Package for the Social Sciences (SPSS) 24.1 (IBM, Armonk, New York), and a scatter plot tool as implemented in R 2.12 (RStudio Team 2015; R Core Team 2016) using the package VEGAN (Oksanen et al. 2013) and SPSS software, respectively.

\section{RESULTS}

Phylogenetic placement of genus Zhurbenkoa and species delimitation.-The final concatenated alignment included 69 sequences of 1828 unambiguous nucleotide positions (28S with 1204 and mrSSU 624 sites), which belong to 65 operational taxonomic units (OTUs). The ML and BI analyses yielded similar topologies. FIG. 1 represents the topology recovered from the ML analysis. The tree is mostly congruent with the recent phylogeny of Lecanoromycetes presented by Miadlikowska et al. (2014). Fifteen well-supported clades were found, corresponding to the known monophyletic families of the Lecanorales, and separated from the outgroup, represented by Lecideales, Peltigerales, and Telochistales. Only the family Lecanoraceae is polyphyletic in our analyses.

Our phylogenetic tree is grouped within two main sister clades corresponding to the suborders Lecanorineae and Sphaerophorineae s.l. (including Psorineae), as delimited by Miadlikowska et al. (2014). Members of Lecanorineae form a strongly supported group (posterior probability $[\mathrm{PP}]=0.99$ ) including Malmideaceae together with seven additional families: Cladoniaceae, Gypsoplacaceae, Lecanoraceae, Parmeliaceae, Ramboldiaceae, Squamarinaceae, and Stereocaulaceae. In contrast to our results, three additional families, Mycoblastaceae, Ramalinaceae, and Tephromelataceae, were included in Lecanorineae by Miadlikowska et al. (2014). The second clade in our analyses represents the suborder Sphaerophorineae s.l. and combines Pilocarpaceae, Psilolechiaceae, Psoraceae, Ramalinaceae s.l., Scoliciosporaceae, and Sphaerophoraceae-affirming the results obtained by Ekman et al. (2008)-with Mycoblastaceae and Tephromelataceae, two families belonging to the sister Sphaerophorineae s.l. clade according to Ekman et al. (2008) and Miadlikowska et al. (2014). This means that although the anatomical characters of Zhurbenkoa suggest its placement within Ramalinaceae s.l. (close to Scutula or Toninia sensu stricto), in our analyses both the families Malmideaceae (including Zhurbenkoa) and Ramalinaceae s.l. (including Toninia cinerea and two lichenicolous species, Scutula tuberculosa and S. miliaris) were resolved as distantly related clades, representing Lecanorineae and Sphaerophorinae s.l., respectively.
The lichenicolous fungi on Cladonia that are our main focus, included in the new genus Zhurbenkoa, were resolved within a strongly supported monophyletic clade including members of the Malmideaceae (Lecanoromycetes) (bootstrap [BS] 93\%, PP 0.99), which includes genera such as Cheiromycina, Kalbionora, Malmidea, Savoronala, and Sprucidea and two poorly known, isolated species, 'Lecidea' cyrtidia and 'L.' plebeja. Such a circumscription of Malmideaceae agrees with previous studies (Kalb et al. 2011; Ertz et al. 2013; Miadlikowska et al. 2014; Cáceres et al. 2017; Muggia et al. 2017; Sodamuk et al. 2017). The two species of Zhurbenkoa included in our analyses formed a highly supported clade (BS 100\%, PP 1) sister to a group including Savoronala madagascariensis, Sprucidea gymnopiperis, and S. rubropenicillata, members of two recently introduced genera from Madagascar and Brazil, respectively (Ertz et al. 2013; Cáceres et al. 2017).

The one-way MANOVA revealed a statistically significant difference among Zhurbenkoa species based on their ascospore sizes, $F(4,1066)=119.38, P<0.0005$, Wilks' $\Lambda=0.477$, partial $\eta^{2}=0.31$. A post hoc Tukey pairwise comparison revealed that the differences were highly significant $(P<0.0005$ or 0.001$)$ for all pairwise groups based on ascospore length or width. These differences are visualized as box plots (FIG. 2) and a scatter plot (FIG. 3). From the box plots, each Zhurbenkoa species can be recognized based on the width of the ascospores, which seems to be the more reliable character to delimit species in the genus. Additionally, the second graph (FIG. 3) shows an evident grouping between each species of Zhurbenkoa. Our results show a relatively clear difference between $Z$. cladoniarum and Z. latispora (the species with aseptate ascospores) in length/breadth ratio and width values of ascospores. The third species, Z. epicladonia, is characterized by the longest ascospores, which are 1septate and narrowly ellipsoidal.

As a consequence of our analyses, we introduce the new genus Zhurbenkoa to accommodate the three species of lichenicolous fungi parasitic on Cladonia (Z. cladoniarum, Z. epicladonia, and Z. latispora) based on their strongly supported isolated position within the family Malmideaceae (BS 100\%, PP 1) and the diagnostic morphological and anatomical characters discussed below.

\section{TAXONOMY}

Zhurbenkoa Flakus, Etayo, Pérez-Ortega and Rodr. Flakus, gen. nov. MycoBank MB828469 


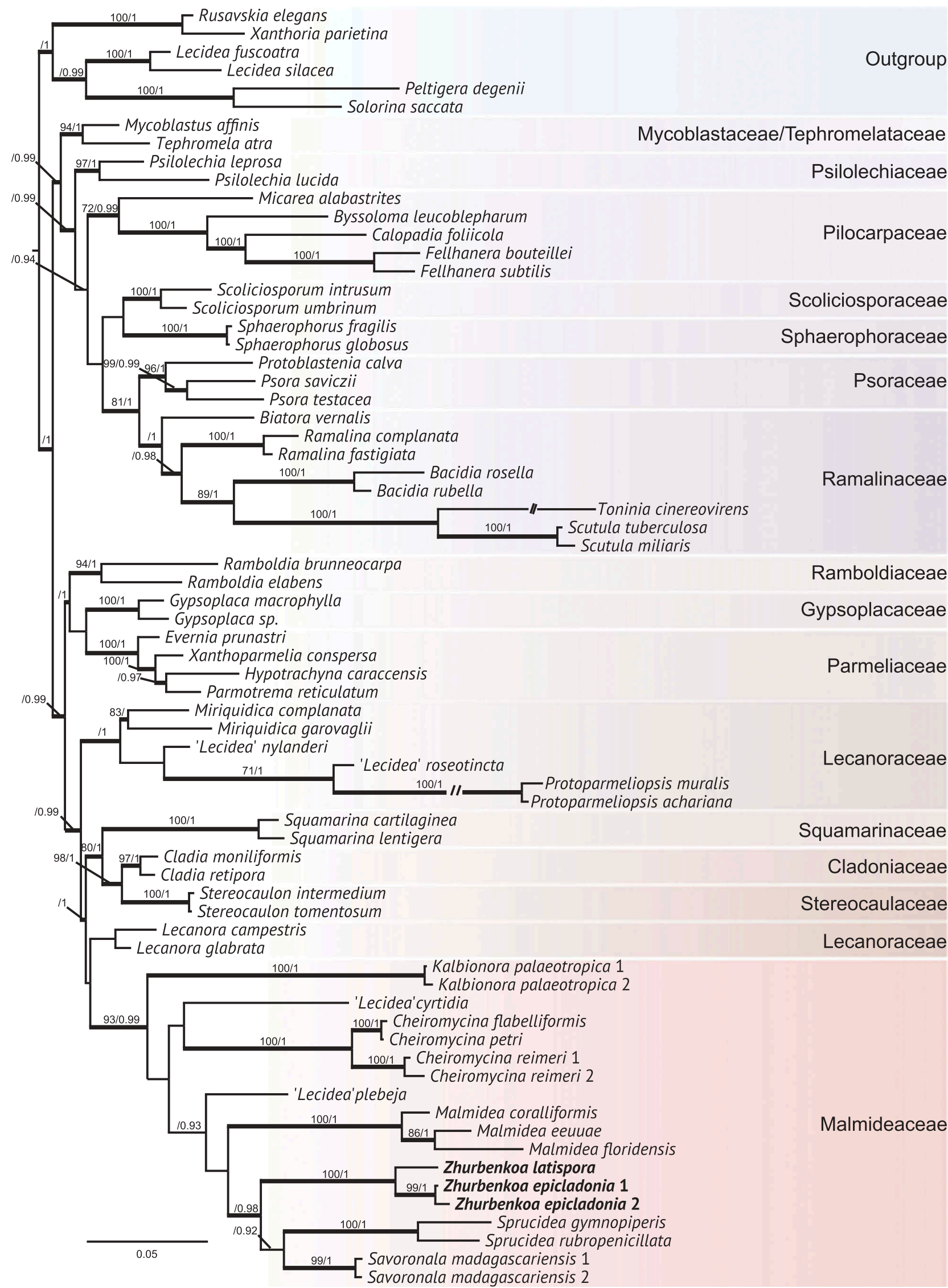

Figure 1. Phylogenetic placement of the genus Zhurbenkoa within Lecanorales inferred from ML analyses of combined mtSSU and $28 \mathrm{~S}$ rDNA data set. Species from the Lecideales, Peltigerales, and Telochistales were used as the outgroup. Bold branches represent either bootstrap values $\geq 70$ and/or Bayesian posterior probabilities $\geq 0.95$. 
(A)

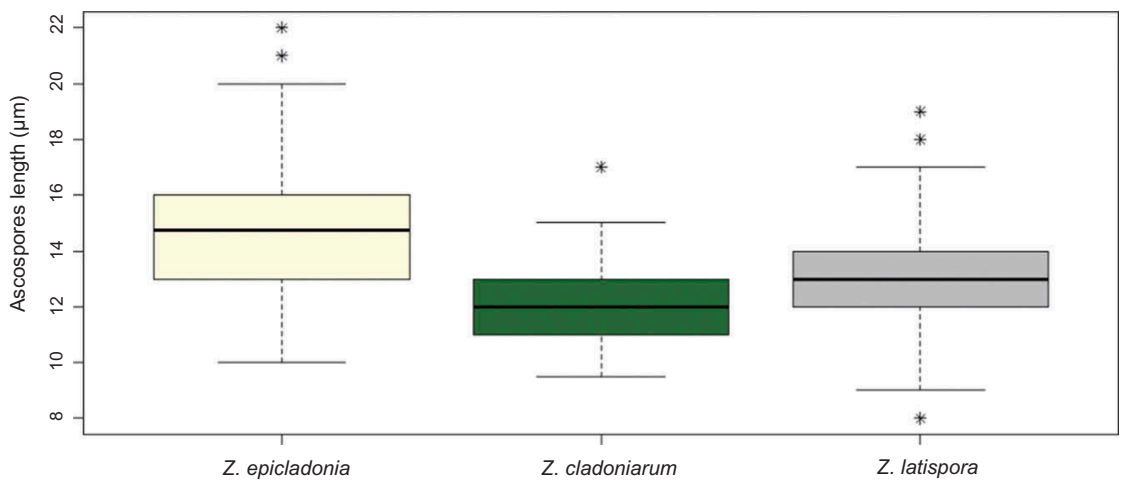

(B)

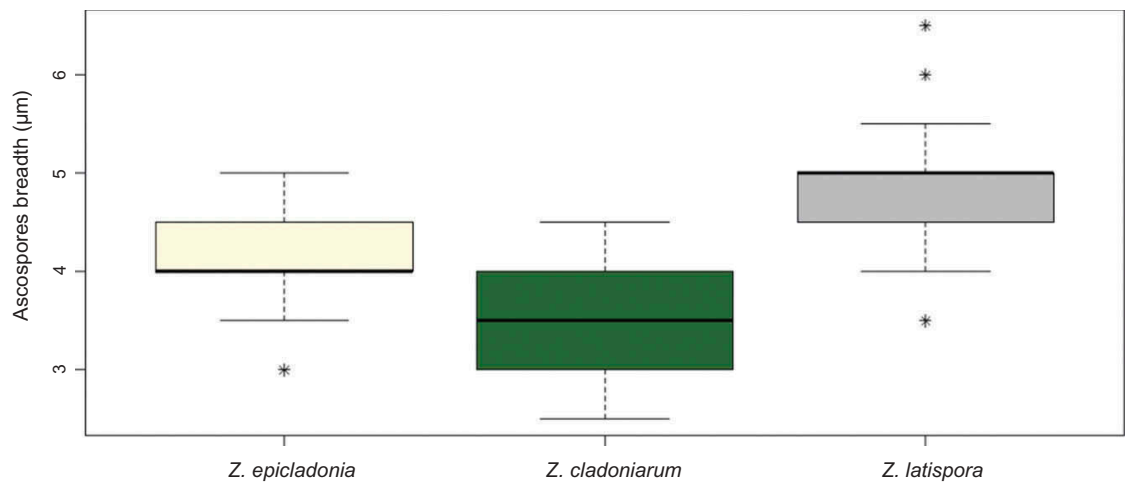

(C)

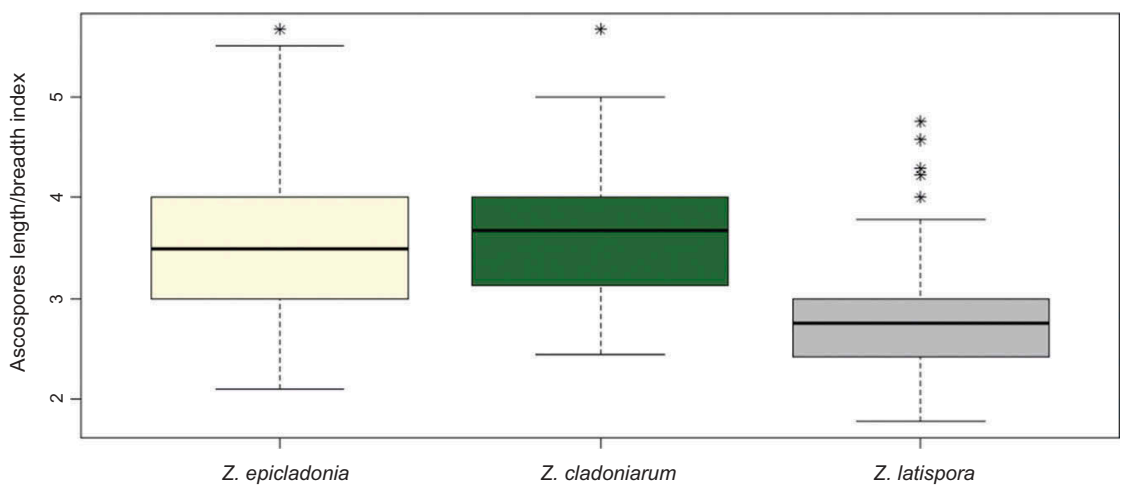

Figure 2. Box plots comparing ascospores measurements between Zhurbenkoa epicladonia, Z. cladoniarum, and Z. latispora. A. Ascospore length. B. Ascospore width. C. Ascospore l/b ratio. Bold vertical lines represent the median values, and asterisks represent outliers.

Typification: Zhurbenkoa epicladonia (Nyl.) Flakus, Etayo, Pérez-Ortega \& Rodr. Flakus.

Etymology: Named in honor of our friend Dr. Mikhail P. Zhurbenko (Saint Petersburg), the prominent Russian lichenologist, for his magnificent contribution to knowledge on the biodiversity and systematics of lichenicolous fungi, including lichen parasites colonizing Cladonia.

Ascomata apothecioid, emarginate, mainly convex, numerous, dispersed on the upper surface of the healthy thallus of the host (Cladonia), almost round, sessile with a slightly constricted base. Disc dark brown to grayish brown or almost black, matte or slightly shiny, epruinose to strongly pruinose, convex. Margin not evident from the beginning, concolorous with the disc. Exciple colorless inside, not interspersed with crystals or oil droplets, I-, composed of strongly gelatinized, radiately arranged hyphae slightly widened apically. Epihymenium colorless, not evident, interspersed with small hyaline or yellowish crystals, $\mathrm{K}+$ dissolving, $\mathrm{N}-$. Hymenium colorless or gray to brownish in the lower part, not interspersed with oil droplets, strongly conglutinate, I+ blue, K/I+ blue. Paraphyses colorless, branched and anastomosed, composed of highly gelatinized hyphae, apically 


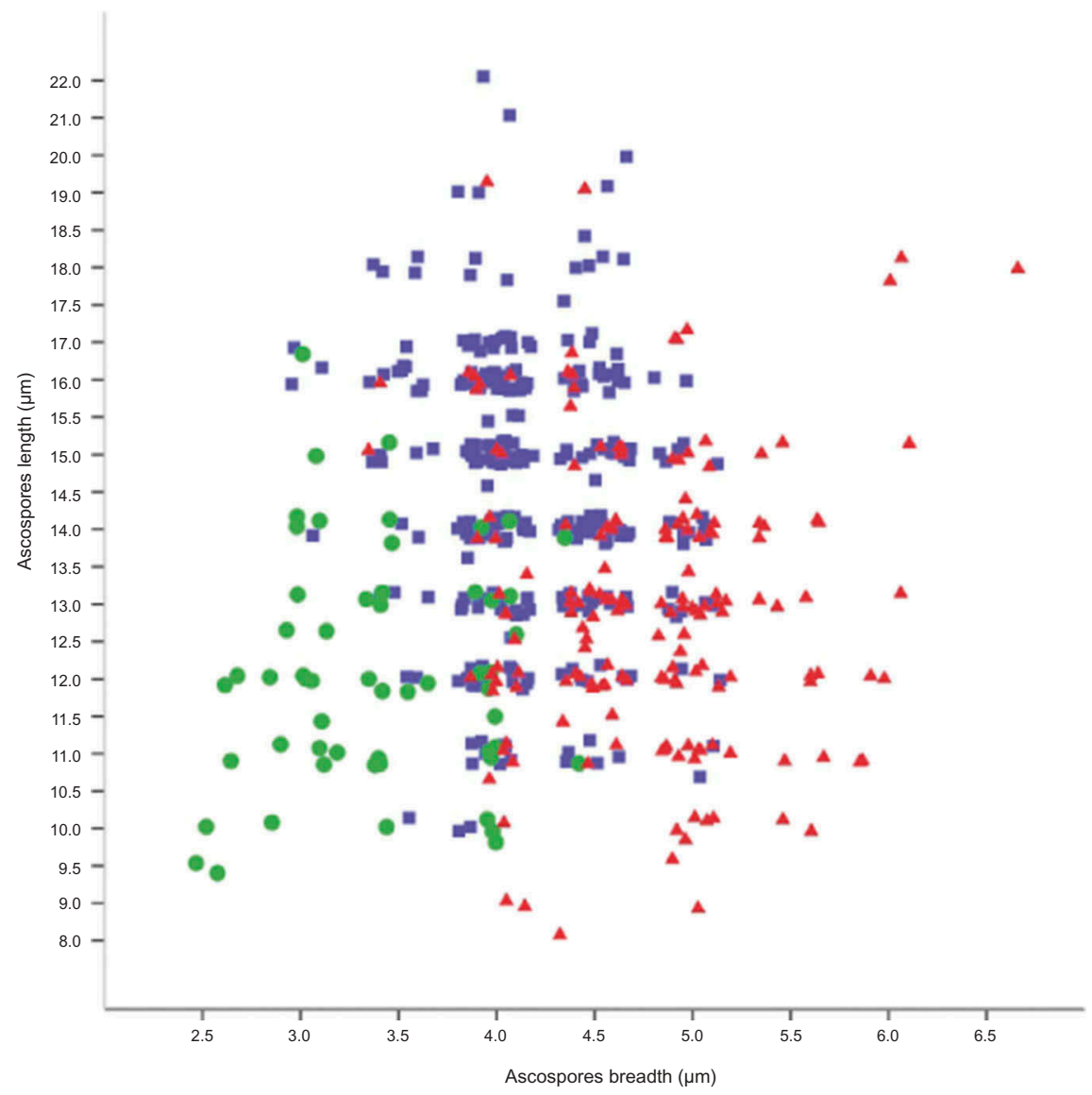

Figure 3. A scatter diagram showing 1074 measurements (in $\mu \mathrm{m}$ ) of ascospore size distribution in three Zhurbenkoa species: $Z$. cladoniarum (circles), Z. epicladonia (squares), and Z. latispora (triangles). Each point may include values from more than one spore.

unthickened, unpigmented. Subhymenium colorless to grayish or pale brown. Hypothecium colorless to gray or brown pigmented $(\mathrm{K}-, \mathrm{N}-)$, composed of highly gelatinized hyphae. Asci 8-spored, clavate, with K/I+ blue apical apparatus, developing in central part a broad hyaline vertical canal (nonamyloid apical cushion) with relatively wide opening at the top (similar to the Lecanora-type ascus apex described by Hafellner [1984] and Ekman et al. [2008]), and surrounded by a dark blue 'tube' (strongly amyloid, slightly darker boundary between nonamyloid apical cushion and moderate amyloid, pale blue apical dome), characteristic of the Micarea-type of ascus as described by Hafellner (1984) and Ekman et al. (2008), representing a transitional stage between Lecanora- and Micarea-type. Ascospores colorless, aseptate to 1-septate, ellipsoidal, sometimes slightly curved, with rounded ends, without an epispore. Conidiomata not seen.

Zhurbenkoa cladoniarum (Müll. Arg.) Flakus, Etayo, Pérez-Ortega \& Rodr. Flakus, comb. nov. FIG. 4 MycoBank MB828559
三 Patellaria cladoniarum Müll. Arg., Hedwigia 30:232. 1891. (Basionym)

Typification: BRAZIL. SANTA CATARINA: Águas Mornas, Theresopolis (Teresópolis) in Serra dos Órgãos, on thallus of Cladonia ceratophylla, 1891, [J.] H. [R.] Schenck 4530 (holotype, G 00290673!). Thinlayer chromatography (TLC) of the host: fumarprotocetraric acid chemosyndrome.

Ascomata apothecioid, emarginate, mainly convex, numerous, dispersed on the upper surface of the healthy thallus of the host, almost round, sessile with a slightly constricted base, (0.15-)0.2-0.3 mm diam. Disc dark brown to grayish brown or rarely almost black, matte or slightly shiny, epruinose. Margin not evident from the beginning, concolorous with the disc. Exciple laterally 40-60(-80) $\mu \mathrm{m}$ wide, basally 40-60(70) $\mu \mathrm{m}$, colorless inside, not interspersed with crystals or oil droplets, I-, composed of strongly gelatinized, radiating hyphae with lumina $0.5-1.5 \mu \mathrm{m}$ wide, sometimes apically slightly widened to $3 \mu \mathrm{m}$. Epihymenium colorless, not evident, ca. $5 \mu \mathrm{m}$ thick, interspersed with small hyaline or yellowish crystals, $\mathrm{K}+$ dissolving, $\mathrm{N}-$. Hymenium colorless or grayish to brownish in the 

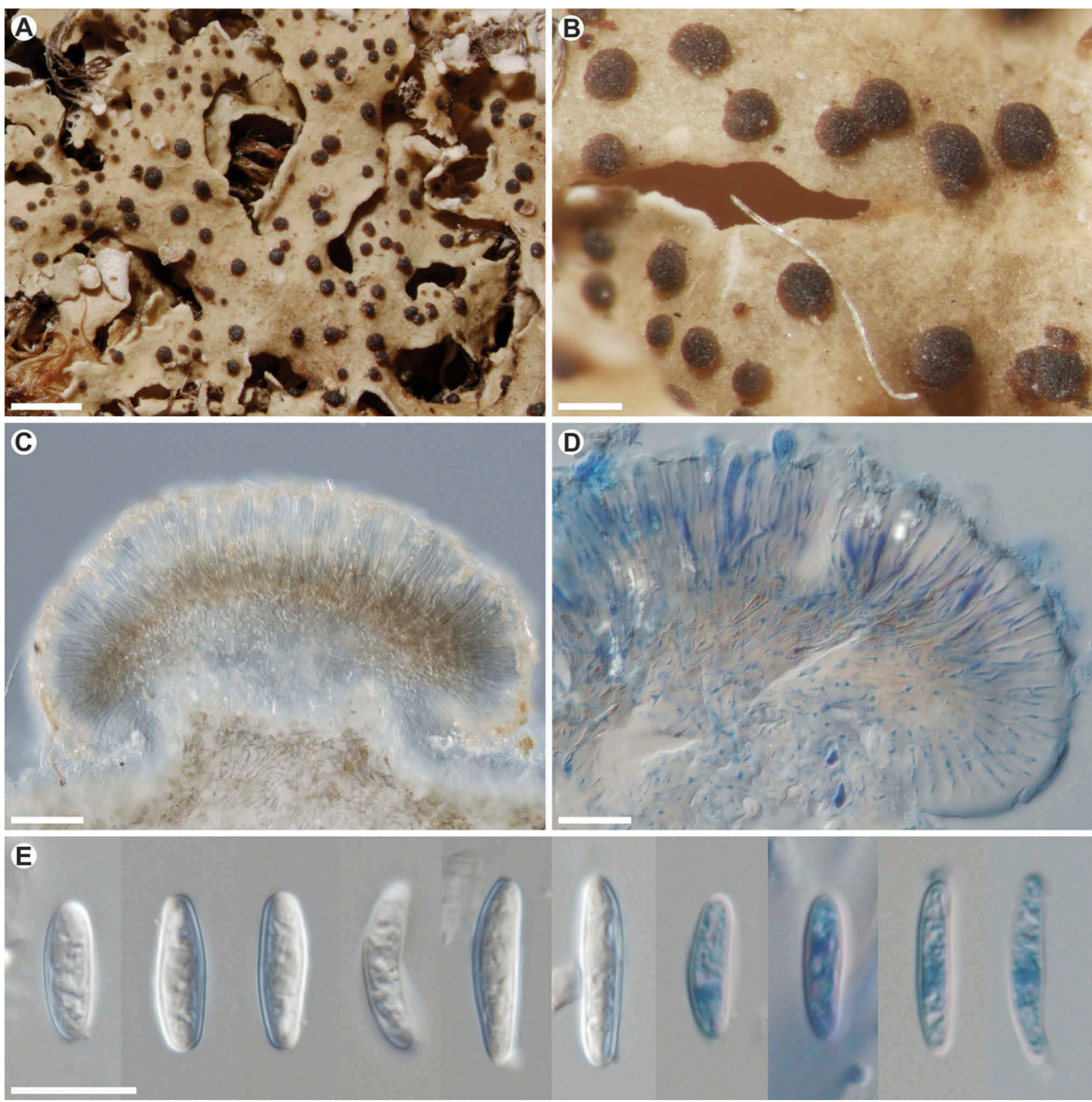

Figure 4. Zhurbenkoa cladoniarum (Schenck 4530, holotype). A, B. Habit of the apothecia dispersed on the upper side of the Cladonia ceratophylla. C. Section of ascoma mounted in tap water. D. Exciple of radiately arranged hyphae mounted in LPCB. E. Ascospores mounted in tap water (left) and LPCB (right). Bars: $A=1 \mathrm{~mm} ; B=250 \mu \mathrm{m} ; C=50 \mu \mathrm{m} ; \mathrm{D}=25 \mu \mathrm{m} ; E=10 \mu \mathrm{m}$.

lower part, not interspersed with oil droplets, $50-80 \mu \mathrm{m}$ high, strongly agglutinated, I+ blue, K/I+ blue. Paraphyses colorless, branched and anastomosed, composed of highly gelatinized hyphae with lumina 1-2 $\mu \mathrm{m}$ wide, apically not thickened, not pigmented. Subhymenium colorless to grayish or pale brown, 10$20 \mu \mathrm{m}$ high. Hypothecium colorless to grayish or brown pigmented $(\mathrm{K}-, \mathrm{N}-)$, composed of intricately arranged highly gelatinized hyphae with lumina 1-1.5 $\mu \mathrm{m}$ wide, $30-60 \mu \mathrm{m}$ high. Asci 8-spored, clavate, with
$\mathrm{K} / \mathrm{I}+$ blue apical apparatus representing a transitional stage between Lecanora- and Micarea-type, 40-55 × 8$14 \mu \mathrm{m}$. Ascospores colorless, aseptate, narrowly ellipsoidal, sometimes slightly curved, with round ends, without an epispore, 9.5- $(\bar{x}=12.1, s=1.5)-17 \times 2.5-$ $(\bar{x}=3.4, s=0.5)-4.5 \mu \mathrm{m}, 1 / \mathrm{b}$ ratio $2.4-(\bar{x}=3.6, s=0.7)-$ $5.7(\mathrm{n}=56)$. Conidiomata not seen.

Host: Zhurbenkoa cladoniarum inhabits the upper thallus surface of primary squamules of Cladonia ceratophylla, producing fumarprotocetraric acid 

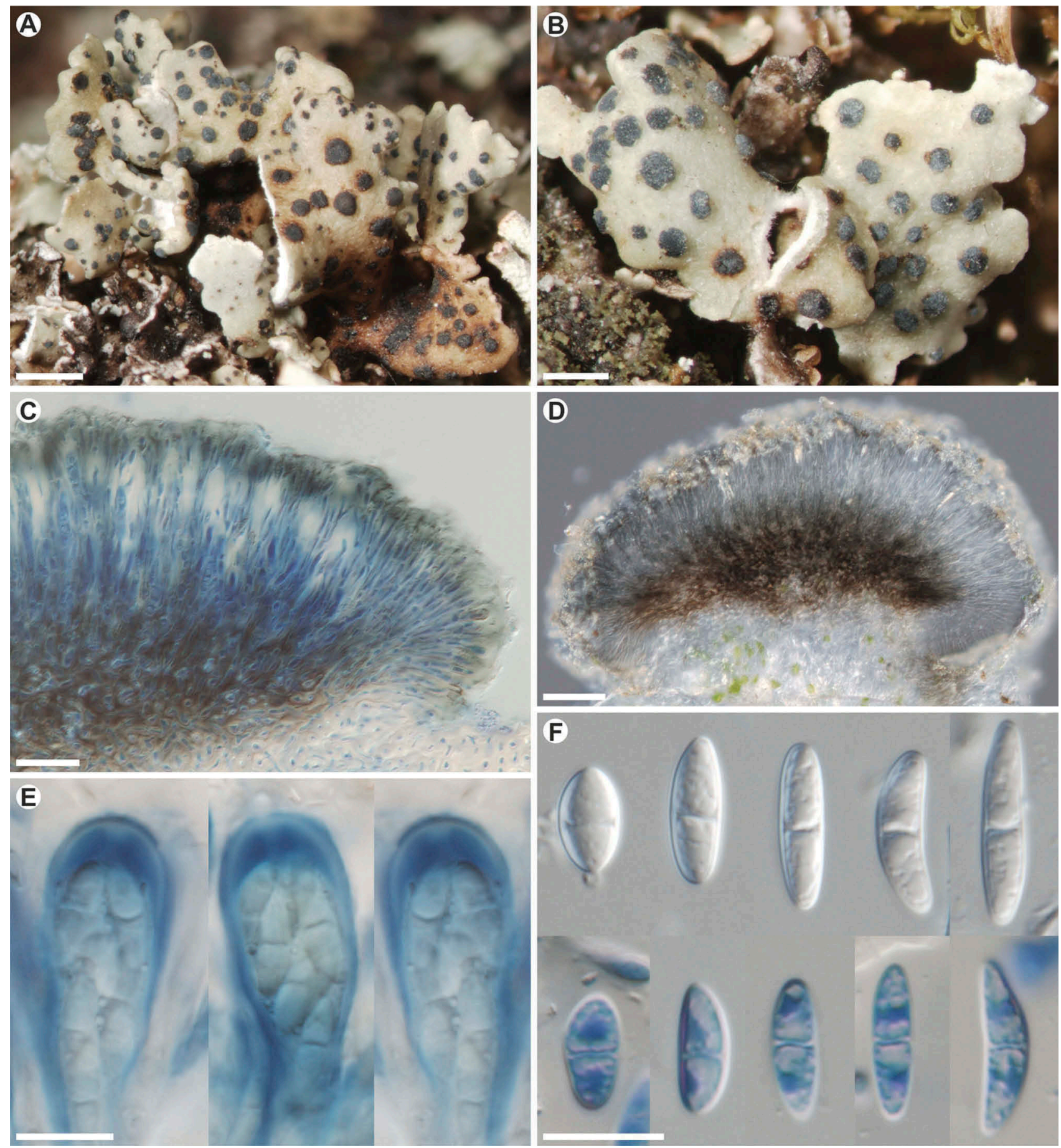

Figure 5. Zhurbenkoa epicladonia (Flakus 25624). A, B. Habit of the apothecia on the upper side of primary squamules of the Cladonia sp. C. Exciple of radiately arranged hyphae mounted in LPCB. D. Section of ascoma mounted in tap water. E. Lecanora/Micarea-type asci mounted in Lugol's iodine solution. F. Ascospores mounted in tap water (upper) and LPCB (lower). Bars: $A=1 \mathrm{~mm}$; $B=500 \mu \mathrm{m}$; $\mathrm{C}=25 \mu \mathrm{m} ; \mathrm{D}=50 \mu \mathrm{m} ; \mathrm{E}-\mathrm{F}=10 \mu \mathrm{m}$.

chemosyndrome. The fungus appears on healthy parts of the thallus, and no damage to the host was observed.

Distribution and habitat: So far, the species is known only from the type locality in Serra dos Órgãos in Brazil (Müller 1891; Gumboski and Elisaro 2011).
Notes: Zhurbenkoa cladoniarum is characterized by dark brown to grayish brown, constantly epruinose ascomata up to $0.3 \mathrm{~mm}$ diam, a pale brown hypothecium, and narrowly ellipsoidal aseptate ascospores. The other two Zhurbenkoa species, Z. epicladonia and Z. 
latispora, have apothecia that are usually pruinose and of slightly different color (grayish when pruinose or almost black) and size (up to $0.5 \mathrm{~mm}$ diam), with a darker hypothecium. They also can be separated by their larger or wider ascospores, respectively, which are $10-(\bar{x}=14.5, s=1.9)-22 \times 3-(\bar{x}=4.2, s=0.4)-5$ $\mu \mathrm{m}$ for Z. epicladonia and $8-(\bar{x}=13.1, s=2)-19 \times 3.5-$ $(\bar{x}=4.8, s=0.6)-6.5 \mu \mathrm{m}$ for Z. latispora. Additionally, $Z$. epicladonia differs by the production of 1-septate ascospores.

Zhurbenkoa epicladonia (Nyl.) Flakus, Etayo, PérezOrtega \& Rodr. Flakus, comb. nov.

FIG. 5 MycoBank MB828560

$\equiv$ Lecidea epicladonia Nyl., Flora 70:132. 1887. (Basionym)

Typification: FRANCE. AVEYRON: Session de Millau, Cévennes Mts., on primary squamules of Cladonia pocillum, Jun 1886, F. [C.] Hy (holotype, HNyl 10962!). TLC of the host: not tested.

$\equiv$ Arthonia epicladonia (Nyl.) Alstrup \& Zhurb., in Zhurbenko \& Alstrup, Symb Bot Upsal 34:478. 2004.

$\equiv$ Biatorina epicladonia (Nyl.) Arnold, Öst Bot Zeitsch 45:106. 1895.

三 Catillaria epicladonia (Nyl.) H. Olivier, Bull Acad Int Géo Bot 15:275. 1905.

三Scutula epicladonia (Nyl.) Zopf, Syll Fung 18:175. 1906.

Ascomata apothecioid, dispersed on the upper side of the healthy thallus of the host (occasionally causing slight hypertrophy), emarginate, immersed at first, soon sessile with a slightly constricted base, moderately to strongly convex, round, (0.1-)0.2-0.4(-0.5) $\mathrm{mm}$ diam. Disc pale to dark gray or almost black, matte, usually strongly grayish pruinose. Margin not evident from the beginning, concolorous with the disc. Exciple laterally 30-60 $\mu \mathrm{m}$ wide, basally $40-50 \mu \mathrm{m}$, colorless inside, not interspersed with crystals or oil droplets, I-, composed of strongly gelatinized, radiating hyphae with lumina 1-2.5 $\mu \mathrm{m}$ wide, sometimes apically slightly widened to $3.5 \mu \mathrm{m}$. Epihymenium pale to dark gray pigmented, $\mathrm{K}+$ orange-brown, $\mathrm{N}-$, 5-10 $\mu \mathrm{m}$ thick, strongly interspersed with small hyaline or yellowish crystals $(\mathrm{K}+$ dissolving, $\mathrm{N}-$ ). Hymenium colorless to grayish blue (with less of the same pigment as in epihymenium), not interspersed with oil droplets, 50-70(-80) $\mu \mathrm{m}$ high, strongly conglutinate, I+ blue, K/I+ blue. Paraphyses colorless, branched and anastomosed, composed of highly gelatinized hyphae with lumina 1-2 $\mu \mathrm{m}$ wide, sometimes apically thickened (to $4.5 \mu \mathrm{m}$ wide) and with pigmented caps. Subhymenium grayish to dark brown, not clear, ca. 5-10 $\mu \mathrm{m}$ high. Hypothecium dark brown to gray-brown pigmented, $\mathrm{K}+$ yellow to orange-brown,
$\mathrm{N}+$ reddish brown, composed of intricately arranged hyphae with lumina 2-3 $\mu \mathrm{m}$ wide, $40-100 \mu \mathrm{m}$ high. Asci 8-spored, clavate, with $\mathrm{K} / \mathrm{I}+$ blue apical apparatus resembling the transitional stage between Lecanoraand Micarea-type, 50-70 × 10-15 $\mu \mathrm{m}$. Ascospores colorless, 1-septate to rarely aseptate, ellipsoidal, sometimes slightly curved, with round ends, without an epispore, $10-(\bar{x}=14.5, s=1.9)-22 \times 3-(\bar{x}=4.2, s=$ $0.4)-5 \mu \mathrm{m}, 1 / \mathrm{b}$ ratio $2.1-(\bar{x}=3.5, s=0.6)-5.7(\mathrm{n}=310)$. Conidiomata not seen.

Host: The species inhabits young terricolous and lignicolous thalli of several species of Cladonia (frequently composed of primary thallus only), producing fumarprotocetraric acid chemosyndrome. The fungus usually appears on healthy parts of the upper surface of primary squamules of the host thallus, but occasionally causes their slight hypertrophy.

Distribution and habitat: Zhurbenkoa epicladonia (as Arthonia epicladonia) is reported from British Isles, Greenland, Papua New Guinea, Russian Arctic, Sweden, Turkey, and USA (Alaska) (Alstrup and Hawksworth 1990; Zhurbenko and Santesson 1996; Aptroot et al. 1997; Zhurbenko 2001; Zhurbenko and Pospelova 2001; Hawksworth 2003; Zhurbenko and Alstrup 2004; Halıc1 et al. 2010), but the majority of these records probably represent Arthonia digitatae (M. Zhurbenko, pers. comm.) or another similar species of Arthonia and should be revised. Although the species may be widespread, we suggest a conservative view of its distribution based only on specimens we studied. Thus, Z. epicladonia is known with certainty from the type locale in the Cévennes Mts. in France (Nylander 1887), the Eastern Carpathians (Ukraine; Kukwa and Zwolicki 2001), and the Andes (Bolivia, Ecuador, Peru). Additional specimens examined: BOLIVIA. DEPT. CHUQUISACA: Prov. Zudañez, Área Natural de Manejo Integrado El Palmar, La Cascada bajo de El Palmar, $18^{\circ} 41^{\prime}$ 23"S, 64 ${ }^{\circ} 54^{\prime} 26^{\prime \prime} \mathrm{W}, 2740 \mathrm{~m}$, Boliviano-Tucumano forest with Podocarpus, Lauraceae, and palms, 15 Jul 2015, P. Rodriguez-Flakus s.n. (LPB); Prov. Carrasco, Parque Nacional Carrasco, between Meruvia and Monte Punku,

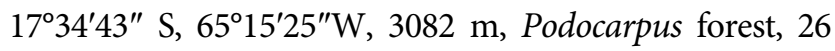
Nov 2014, A. Flakus 25624 (KRAM, LPB; TLC: fumarprotocetraric acid); Prov. Tiraque, Parque Nacional Carrasco, the crossroad below Cerro Juno, $17^{\circ} 19^{\prime} 50^{\prime \prime}$ S, $65^{\circ} 43^{\prime} 50^{\prime \prime} \mathrm{W}$, $4126 \mathrm{~m}$, open high Andean vegetation, 29 Nov 2014, A. Flakus 25937 (KRAM, LPB; TLC: fumarprotocetraric acid); DEPT. LA PAZ: Prov. Franz Tamayo, Área Natural de Manejo Integrado Nacional Apolobamba, road Pelechuco-Keara near the turnoff to Puina, $14^{\circ} 41^{\prime} 23^{\prime \prime} \mathrm{S}$, $69^{\circ} 08^{\prime} 02^{\prime \prime} \mathrm{W}, 4370 \mathrm{~m}$, open high Andean vegetation, 17 Nov 2014, A. Flakus 25212 (KRAM, LPB; TLC: fumarprotocetraric acid); Aguas Blancas, close to Pelechuco-Sorta 
road, $14^{\circ} 47^{\prime} 52^{\prime \prime} \mathrm{S}, 69^{\circ} 08^{\prime} 51^{\prime \prime} \mathrm{W}, 4396 \mathrm{~m}$, open high Andean vegetation, 20 Nov 2014, A. Flakus 25474 (KRAM, LPB; TLC: fumarprotocetraric acid); DEPT. TARIJA: Prov. Aniceto Arce, Reserva Nacional de Flora y Fauna de Tariquía, between la Cumbre and campamento los Alisos, $22^{\circ} 00^{\prime} 41^{\prime \prime} \mathrm{S}, 64^{\circ} 36^{\prime} 02^{\prime \prime} \mathrm{W}, 2560 \mathrm{~m}$, Boliviano-Tucumano forest with Alnus acuminata and Polylepis, 22 Jul 2016, on Cladonia squamules growing on epiphytic Parmotrema, J. Etayo 30348 (LPB, herb. Etayo). ECUADOR. PROV. COTOPAXI: N. P. Cotopaxi, NNE slope of the volcano Cotopaxi, a more than 100 -y-old lava flow, $00^{\circ} 37^{\prime} \mathrm{S}, 78^{\circ} 24^{\prime}$ W, $3840 \mathrm{~m}$, on squamules of terricolous Cladonia sp., 27 Jun 1999, Z. Palice 2910 (PRA; TLC: fumarprotocetraric acid); $00^{\circ} 36^{\prime} 45^{\prime \prime} \mathrm{S}, 78^{\circ} 24^{\prime} 15^{\prime \prime} \mathrm{W}, 3800 \mathrm{~m}$, on squamules (rarely podetia) of Cladonia chlorophaea, eroding slope by the brook, 27 Jun 1999, Z. Palice 2534 (PRA; TLC: fumarprotocetraric acid). PERU. DEPT. AREQUIPA: Prov. Caylloma, Cañon del Colca above Tapay village, open mountain area, $3705 \mathrm{~m}, 7 \mathrm{Jul} 2006,1^{\circ} 33^{\prime} 56^{\prime \prime} \mathrm{S}, 71^{\circ} 55^{\prime} 32^{\prime \prime}$ W, A. Flakus 9708 (KRAM; TLC: fumarprotocetraric acid); DEPT. CUSCO: Prov. Anta, North of Zurite, a trail to queñua (Polylepis sp.) forest, $3794 \mathrm{~m}, 13^{\circ} 26.133^{\prime} \mathrm{S}, 72^{\circ}$ $15.196^{\prime} \mathrm{W}$, on squamules of Cladonia sp., 25 Oct 2010, S. Pérez-Ortega 2870 (MA-Lichen; TLC: fumarprotocetraric acid). UKRAINE. EASTERN CARPATHIANS: Chivchino-Grinyavskie Mts., below Budyjowska Wielka on squamules of Cladonia sp. growing on calcareous soil, 18 Jul 1935, T. Sulma s.n. (UGDA L-15357; TLC: fumarprotocetraric acid).

Notes: Zhurbenkoa epicladonia was described as Lecidea epicladonia and was found growing on Cladonia pocillum in France by Nylander (1887). For a long time, its systematic position was uncertain, and various taxonomists tried to resolve its relationships based on different anatomical characters. Consequently, the species was included in various genera, e.g., Biatorina (Arnold 1895), Catillaria (Olivier 1905), or Scutula (Saccardo and Saccardo 1906). Later, Alstrup and Hawksworth (1990) reported Arthonia-type asci in Greenland specimens (Christiansen 5574, as Scutula epicladonia) and suggested that the generic position of the species needed further study. Zhurbenko and Alstrup (2004), based on specimens collected in Alaska and the drawings of the sample from Greenland, proposed to transfer the species into Arthonia (Arthoniomycetes). Recently, our study on the type collection of Lecidea epicladonia revealed that the specimen has a well-developed exciple and asci of Lecanora/Micarea-type, critical characters that clearly exclude it from Arthonia.

Zhurbenkoa latispora Flakus, Etayo, Pérez-Ortega \& Rodr. Flakus, sp. nov. FIG. 6 MycoBank MB828561
Typification: BOLIVIA. DEPT. LA PAZ: Prov. Franz Tamayo, Parque Nacional y Área Natural de Manejo Integrado Madidi, Chuñuna above Keara, $14^{\circ} 41^{\prime} 11^{\prime \prime} \mathrm{S}$, 69 $05^{\prime} 30^{\prime \prime} \mathrm{W}, 4053 \mathrm{~m}$, Polylepis pepei forest, on terricolous Cladonia, 19 Nov 2014, A. Flakus 25452 (holotype KRAM L-70178!). Isotype LPB! TLC of the host: sekikaik and homosekikaik acids chemosyndrome.

Etymology: lata (Latin), referring to the broadly ellipsoidal ascospores.

Diagnosis: Differs from other Zhurbenkoa species by having uniformly aseptate and broadly ellipsoidal ascospores, $8-(\bar{x}=13.1, s=2)-19 \times 3.5-(\bar{x}=4.8, s=0.6)-6.5$ $\mu \mathrm{m}, \mathrm{l} / \mathrm{b}$ ratio $1.8-(\bar{x}=2.8, s=0.6)-4.8$.

Ascomata apothecioid, dispersed on the upper surface of the healthy thallus of the host, emarginate, immersed at first, soon sessile with a slightly constricted base, moderately to strongly convex, round, $(0.1-) 0.2-0.4(-0.5) \mathrm{mm}$ diam. Disc pale to dark gray or black, matte to shiny, strongly grayish pruinose or epruinose. Margin not evident from the beginning, concolorous with the disc. Exciple laterally 40-60 $\mu \mathrm{m}$ wide, basally 30-50 $\mu \mathrm{m}$, colorless inside, not interspersed with crystals or oil droplets, I-, composed of strongly gelatinized, radiating hyphae with lumina 1-2 $\mu \mathrm{m}$ wide, sometimes apically slightly widened to $3 \mu \mathrm{m}$. Epihymenium pale to dark gray pigmented, $\mathrm{K}+$ orangebrown, N-, 5-10 $\mu \mathrm{m}$ thick, strongly interspersed with small hyaline or yellowish crystals $(\mathrm{K}+$ dissolving, $\mathrm{N}-$ ). Hymenium colorless to grayish blue, with a lesser amount of the same pigment as the epihymenium, not interspersed with oil droplets, 50-70(-80) $\mu \mathrm{m}$ high, strongly conglutinate, I+ blue, K/I+ blue. Paraphyses colorless, branched and anastomosed, composed of highly gelatinized hyphae with lumina 1-2 $\mu \mathrm{m}$ wide, sometimes apically thickened (to $5 \mu \mathrm{m}$ wide) and with pigmented caps. Subhymenium grayish to dark brown, not evident, ca. 5-10 $\mu \mathrm{m}$ high. Hypothecium dark brown to gray-brown pigmented, $\mathrm{K}+$ yellow to orange-brown, $\mathrm{N}+$ reddish brown, composed of hyphae giving the appearance of paraplectenchymatous tissue, with lumina 2-3 $\mu \mathrm{m}$ wide, sometimes strongly penetrating host thallus, 30-120 $\mu \mathrm{m}$ high. Asci 8-spored, clavate, with $\mathrm{K} / \mathrm{I}+$ blue apical apparatus resembling the transitional form between Lecanora- and Micareatype, $40-55 \times 10-14 \mu \mathrm{m}$. Ascospores colorless, aseptate, broadly ellipsoidal, sometimes slightly curved or narrowed at the top, without an epispore, $8-(\bar{x}=13.1, s=$ $2)-19 \times 3.5-(\bar{x}=4.8, s=0.6)-6.5 \mu \mathrm{m}, 1 / \mathrm{b}$ ratio $1.8-(\bar{x}=$ $2.8, s=0.6)-4.8(\mathrm{n}=171)$. Conidiomata not seen.

Host: Upper surface of squamules of the primary and secondary thalli of various terricolous and lignicolous species of Cladonia, producing atranorin, sekikaic and homosekikaic acids, or fumarprotocetraric acid 

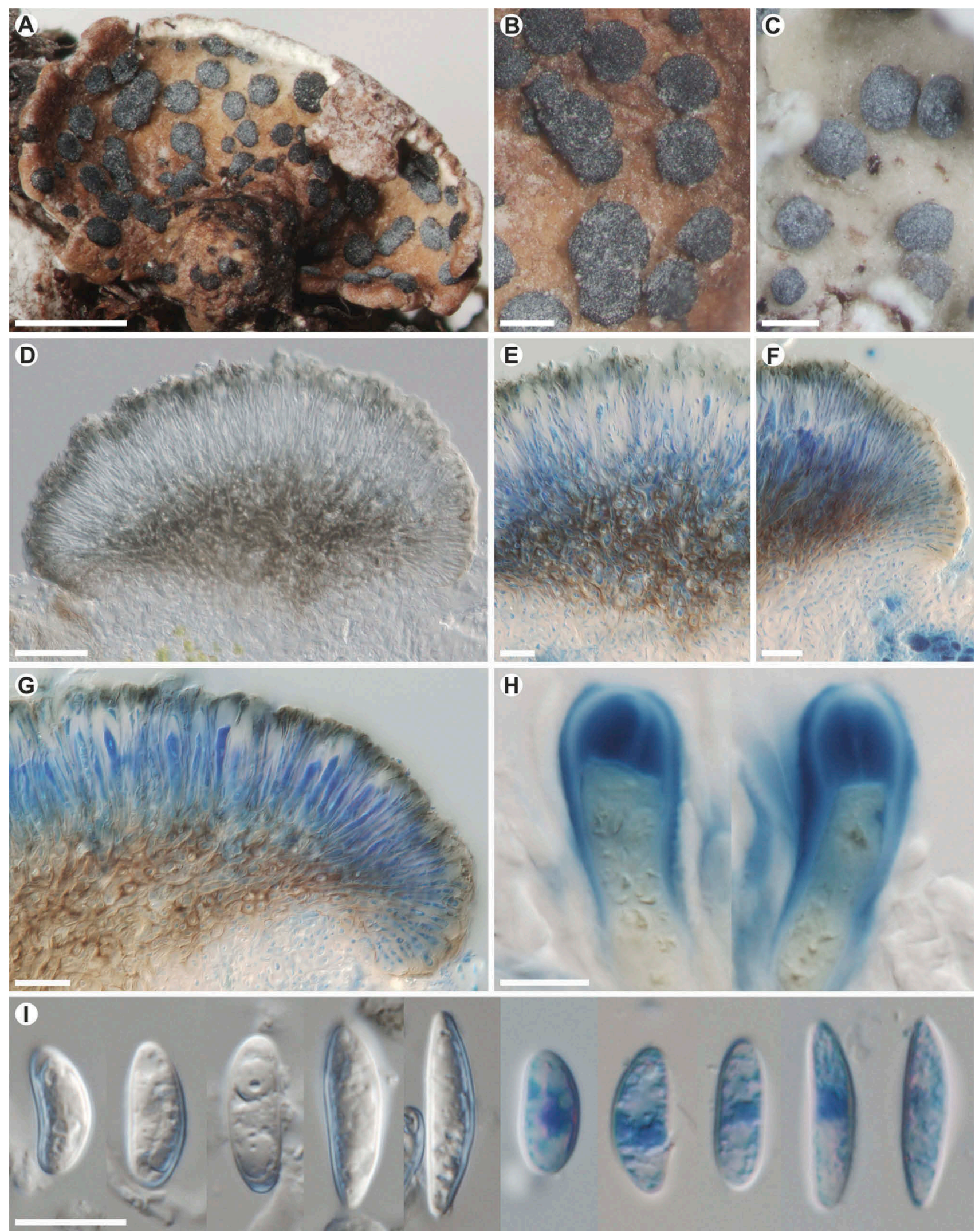

Figure 6. Zhurbenkoa latispora (all except C based on Flakus 25452, holotype). A, B. Habit of the apothecia on the upper side of primary squamules of the Cladonia sp. C. Apothecia on the podetial squamules of C. rappii (Flakus 4722/1). D. Section of ascoma mounted in tap water. E. Darkly pigmented hypothecium mounted in LPCB. F, G. Exciple of radiately arranged hyphae mounted in LPCB. H. Lecanora/Micarea-type asci mounted in Lugol's iodine solution. I. Ascospores mounted in tap water (left) and LPCB (right). Bars: $A=1 \mathrm{~mm} ; \mathrm{B}-\mathrm{C}=250 \mu \mathrm{m} ; \mathrm{D}=50 \mu \mathrm{m} ; \mathrm{E}=20 \mu \mathrm{m} ; \mathrm{F}-\mathrm{G}=25 \mu \mathrm{m} ; \mathrm{H}-\mathrm{I}=10 \mu \mathrm{m}$. 
chemosyndromes. The fungus appears on healthy parts of the host thallus.

Distribution and habitat: The species is known only from mountain areas in South America (Bolivia and Ecuador).

Additional specimens examined: BOLIVIA. DEPT. SANTA CRUZ: Prov. Manuel María Caballero, Siberia region near La Palma village, $17^{\circ} 49^{\prime} 12^{\prime \prime} \mathrm{S}, 64^{\circ} 40^{\prime} 28^{\prime \prime} \mathrm{W}$, $2582 \mathrm{~m}$, Yungas cloud forest, on podetia and squamules of C. rappii, 13 Dec 2004, A. Flakus 4722/1 (KRAM, LPBL; TLC: fumarprotocetraric acid). ECUADOR. PROV. AZUAY: Area Nacional de Recreación Cajas, Laguna Torreadora, $02^{\circ} 46^{\prime} 50^{\prime \prime} \mathrm{S}, \quad 79^{\circ} 13^{\prime} 40^{\prime \prime} \mathrm{W}$, on Cladonia sp., vertical side of a mossy boulder near the lake, 4100 m, 2 Aug 1999, J. Etayo \& Z. Palice 3193 (PRA; TLC: sekikaic and homosekikaic acids); PROV. IMBABURA: Laguna Cuicocha, NE edge, ca. $9 \mathrm{~km} \mathrm{~W}$ of town Cotacachi, $00^{\circ} 18^{\prime} 43^{\prime \prime} \mathrm{N}, 78^{\circ} 21^{\prime} 15^{\prime \prime} \mathrm{E}$, on squamules of Cladonia sp., trail cutting, 3300-3350 m, 8 Oct 2000, Z. Palice 4451 \& Z. Soldán (PRA; TLC: atranorin and unidentified fatty acid).

Notes: Within Zhurbenkoa, this new species is characterized by the widest and broadly ellipsoidal ascospores. It further differs from Z. epicladonia by its aseptate ascospores.

\section{KEY TO SPECIES OF ZHURBENKOA}

1. Ascospores mostly 1-septate; widespread.................................... Z. epicladonia

$1^{\prime}$. Ascospores aseptate; Neotropical..................2

2. Ascospores narrowly ellipsoidal, $9.5-(\bar{x}=12.1, s=$ $1.5)-17 \times 2.5-(\bar{x}=3.4, s=0.5)-4.5 \mu \mathrm{m}, 1 / \mathrm{b}$ ratio $2.4-(\bar{x}=3.6, \quad s=0.7)-5.7 ; \quad$ Brazil .................................... Z. cladoniarum

$2^{\prime}$. Ascospores broadly ellipsoidal, $8-(\bar{x}=13.1, s=$ $2)-19 \times 3.5-(\bar{x}=4.8, s=0.6)-6.5 \mu \mathrm{m}, 1 / \mathrm{b}$ ratio $1.8-(\bar{x}=2.8, s=0.6)-4.8$; Bolivia, Ecuador Z. latispora

\section{DISCUSSION}

The newly described lichen genus Zhurbenkoa is recognized by following characters: (i) gray-brown to almost black emarginate apothecia; (ii) an epihymenium interspersed with crystals (often seen as pruina); (iii) a strongly conglutinated hymenium composed of noncapitate and sparsely branched and anastomosed paraphyses; (iv) a colorless exciple composed of radiately arranged hyphae; (v) a Lecanora/Micarea-like ascus type; (vi) aseptate or 1-septate ellipsoidal, colorless ascospores without an epispore; and (vii) the lichenicolous lifestyle and specific host association (Cladonia).

Although the main morphological features of the type material of Zhurbenkoa and additional specimens studied here suggest that species of this genus are similar to those of Scutula and Toninia s.l., the phylogenetic analyses clearly indicate their affinities to Malmideaceae rather than Ramalinaceae s.l. (FIG. 1). Lichenicolous species of several fungal genera (Clauzade et al. 1989), such as Arthonia, Carbonea, Catillaria, Micarea, Phacopsis s.l., Scutula, Tephromela, and Toninia s.l., can be easily confused with Zhurbenkoa because of similar apothecial appearance, 8-spored asci, and the production of aseptate to transversely septate colorless ascospores. However, they substantially differ from Zhurbenkoa by their contrasting phylogenetic affinities, outside of the Malmideaceae, and a specific set of the following key characters: (i) Arthonia (Arthoniomycetes), absence of or with a strongly reduced exciple and Arthonia-type asci (Grube and Matzer 1997); (ii) Carbonea (Lecanoraceae), with a darkly pigmented inner exciple, the upper part of hymenium with aeruginose pigment, thin anastomosed paraphyses, and different host preferences, mainly saxicolous crustose lichens (Hertel 1983; Knoph et al. 2004; Pirogov et al. 2014); (iii) Catillaria (a polyphyletic assemblage in Lecanoromycetes), Catillariatype asci, and strongly capitate simple paraphyses with pigmented cups (Kilias 1981; Hafellner 1982; Etayo 2000); (iv) Micarea (Pilocarpaceae), absence of or with a strongly reduced exciple, thin strongly anastomosing paraphyses, comparatively thinner ascospores, and in general presence of a lichenized thallus (Coppins 1983; Van den Boom and Ertz 2014; Brackel 2016; Etayo 2017); (v) Phacopsis s.l. (Parmeliaceae), ascomata immersed in host thallus, dark brown to black and shiny, often gall-inducing, reduced exciple, paraphyses apically swollen with dark brown-pigmented caps, inhabiting various genera of Parmeliaceae (Hafellner1987; Triebel et al. 1995; Peršoh and Rambold 2002; Divakar et al. 2015); (vi) Scutula (Ramalinaceae s.l.), apothecia always black with a distinct margin, asci of the Scutula-type, exciple usually with greenish brown to red-brown pigments, hosts mainly from Peltigeraceae (Triebel et al. 1997; Wedin et al. 2007); (vii) Tephromela (Tephromelataceae; position of lichenicolous members unknown), apothecial sections with a violet pigment $(\mathrm{N}+$ red), asci of the Bacidia-type, growing on Dirinaria and Lecanora (Rambold and Triebel 1992; Rambold 1993); and (viii) Toninia s.l. (Ramalinaceae), paraphyses strongly swelled apically, an apothecial section with different pigments (e.g., gray, green, reddish brown; frequently reacting $\mathrm{N}+$ violet or $\mathrm{K}$ + violet), asci of the Bacidia-type, and ascospores usually 
more than 1-septate and/or larger (Timdal 1992; Etayo and Sancho 2008; Kistenich et al. 2018).

A revised classification of Lecanoromycetes, just published by Kraichak et al. (2018), confirmed the isolated position of Malmideaceae within Lecanoromycetes, strongly supported as a sister to Pilocarpaceae. As circumscribed previously, the family Malmideaceae was represented exclusively by lichen-forming Ascomycetes developing symbiotic associations with green chlorococcoid algae of still unknown identity (Kalb et al. 2011; Ertz et al. 2013; Miadlikowska et al. 2014; Cáceres et al. 2017; Muggia et al. 2017; Sodamuk et al. 2017). This kind of mutualism plays essential role in evolution of the whole Lecanoromycetes, the most speciose class of lichen-forming fungi (Miadlikowska et al. 2014). Reversions to other nutritional strategies are rare in that class. Lichenicolous trophic modes, although very rare, repeatedly evolved through the Lecanoromycetes. Recent molecular evidence suggests that such events occurred in various families of the class, for example in Acarosporaceae (Sarcogyne sphaeospora), Lecanoraceae (Carbonea supersparsa, C. vitellinaria), Parmeliaceae (Nesolchia oxyspora, Phacopsis vulpina, Raesaenenia huuskonenii), Pilocarpaceae (Epicladonia simplex, E. stenospora, Micarea usneae), or Ramalinaceae (Scutula epiblastematica, S. tuberculosa, S. miliaris, Toninia plumbina) (Diederich et al. 2018 and papers cited therein). Zhurbenkoa species, however, are the first lichenicolous fungi discovered in Malmideaceae, and all other members of the family differing by an evident lichenized thallus. At the moment, the Malmideaceae contains (including Zhurbenkoa) 62 species spread across seven genera, including 2 species of unknown generic position that are temporarily placed in Lecidea s.l. ('L.' cyrtidia and 'L.' plebeja).

Specimens of Zhurbenkoa are quite uniform in their apothecial anatomy. However, size and septation of ascospores are variable. Our preliminary analysis on a moderate number of ascospore measurements showed no evident patterns, and we at first thought that the genus included two species, one with aseptate and the other with septate ascospores. This hypothesis was supported by our phylogenetic analyses, which showed an obvious distinction between samples with septate and aseptate ascospores. When comparing only the length of ascospores specimens formed two groups (FIG. 2A), one with large and septate ascospores (Z. epicladonia) and the other one with short and aseptate ascospores ( $Z$. cladoniarum, $Z$. latispora). But when the average values of ascospore width were compared, three groups were clear (FIG. 2B), characterized by medium (Z. epicladonia), narrowest (Z. cladoniarum), and widest (Z. latispora) ascospores. A comparison of $1 / b$ ratios consolidated specimens in two groups (FIG. 2C), one producing relatively narrow ascospores (Z. cladoniarum, Z. epicladonia) and the second with broadly ellipsoidal ascospores (Z. latispora). A scatter diagram, for which 1074 measurements of the ascospores size were analyzed, showed three different clusters, representing Z. epicladonia, Z. cladoniarum, and Z. latispora (FIG. 3). Taking into consideration the results of the phylogenetic and statistical analyses together, we decided to distinguish three species within Zhurbenkoa: (i) Z. epicladonia for specimens with narrowly ellipsoidal, large and relatively wide, and septate ascospores; (ii) $Z$. cladoniarum for specimens with narrowly ellipsoidal, short and narrow, aseptate ascospores; and (iii) Z. latispora for specimens with broadly ellipsoidal, short and wide, aseptate ascospores.

Cladonia is a widespread lichen genus, the largest in the Cladoniaceae (Lecanoromycetes), with about 500 species (Stenroos et al. 2002), which frequently hosts lichenicolous fungi. Recent studies compiled up to 138 species of lichenicolous fungi inhabiting Cladonia (Zhurbenko and Pino-Bodas 2017); some of these could be mistaken for Zhurbenkoa. Micarea kemmleri, recently described from podetia of Cladonia squamosa from Germany, differs by having unpigmented, pale straw yellow, biatorine apothecia, a different kind of exciple, thinner and strongly branched paraphyses, an ascus apex with a narrower canal surrounded by K/I+ dark blue tube (reminiscent of the ascus type of Pilocarpaceae), and much smaller ascospores, 6-9 $\times$ 2.5-4 $\mu \mathrm{m}$ (Brackel 2016). The species presently is known from a single specimen, and further molecular studies are necessary to establish its phylogenetic position. Bachmanniomyces punctum (Trapeliales; Diederich et al. 2018) induces gall formation on the podetia and squamules of Cladonia and can be recognized by smaller black apothecia up to $0.2 \mathrm{~mm}$ diam), an ascus apex lacking evident structures, and small ascospores, $7-11 \times 2.5-4 \mu \mathrm{m}$. Brackelia lunkei can be confused at first sight with very young specimens of Zhurbenkoa, but in contrast it has very small ascomata, only up to $0.12 \mathrm{~mm}$ diam, K/I- asci, sometimes forms capitate and brown-pigmented paraphyses, and produces smaller ascospores, 5.5-11 $\times 2.5-4 \mu \mathrm{m}$ (Zhurbenko and Pino-Bodas 2017). Additionally, species of Abrothallus, Sclerococcum (syn. Dactylospora) and Arthonia species growing on Cladonia may have similar apothecia but produce darkly pigmented ascospores with more septa and/or a reduced exciple (for detailed information, see Zhurbenko and Pino-Bodas 2017). Additionally, Lecanora lecanoricola, described from Greenland, a species of unknown phylogenetic position having dark and pruinose lecideoid apothecia (Alstrup and Hawksworth 1990), might be confused with Zhurbenkoa, especially $Z$. latispora. It differs, 
however, by the presence of a greenish pigment in apothecial sections, an exciple composed of apically swollen hyphae up to $6(-8) \mu \mathrm{m}$ wide that may be indistinct when mature, apically swollen paraphyses up to 4 um wide, and host selection, because the species is an obligate parasite of saxicolous Lecanora cenisia (Alstrup and Hawksworth 1990).

\section{ACKNOWLEDGMENTS}

We are greatly indebted to our colleagues and all staff of the Herbario Nacional de Bolivia, Instituto de Ecología, Universidad Mayor de San Andrés, La Paz, for their generous long-term cooperation. We would also like to thank the SERNAP (http:// sernap.gob.bo), and all protected areas staff, for providing permits for scientific studies, as well as their assistance and logistical support during the field works. We thank especially Paul Diederich (Luxembourg) and an anonymous reviewer for their valuable comments on the manuscript, and also the curators of the cited herbaria for a loan of the specimens used in the study.

\section{FUNDING}

This research was financially supported by the National Science Centre (NCN) in Poland (DEC-2013/11/D/NZ8/ 03274). A.F. and P.R.F. received additional support under statutory funds from the W. Szafer Institute of Botany, Polish Academy of Sciences, Krakow, Poland. S.P.O. was supported by the grant RYC-2014-16784 from the Spanish Ministry of Economy, Industry, and Competitiveness. Z.P. acknowledges the support by the Academy of Science of the Czech Republic (AV0Z60050516, RVO 67985939).

\section{ORCID}

Adam Flakus (D) http://orcid.org/0000-0002-0712-0529 Javier Etayo (D http://orcid.org/0000-0003-0392-0710 Sergio Pérez-Ortega (D) http://orcid.org/0000-0002-5411-3698 Martin Kukwa (D) http://orcid.org/0000-0003-1560-909X Zdeněk Palice (D) http://orcid.org/0000-0003-4984-8654 Pamela Rodriguez-Flakus (D) http://orcid.org/0000-00018300-5613

\section{LITERATURE CITED}

Alstrup V, Hawksworth DL. 1990. The lichenicolous fungi of Greenland. Meddelelser om Grønland, Bioscience 31:1-90.

Altschul SF, Gish W, Miller W, Myers EW, Lipman DJ. 1990. Basic local alignment search tool. Journal of Molecular Biology 215:403-410.

Aptroot A, Diederich P, Serusiaux E, Sipman HJM. 1997. Lichens and lichenicolous fungi from New Guinea. Bibliotheca Lichenologica 64:1-220.

Arnold F. 1895. Lichenologische Fragmente 34. Österreichische Botanische Zeitschrift 45: 60-63,106-109, 146-147, 1 pl.

Brackel W von. 2016. Eine neue flechtenbewohnende Micarea-Art aus Baden-Württemberg. Carolinea 74:5-9.
Breuss O, Lücking R. 2015. Three new lichen species from Nicaragua, with keys to the known species of Eugeniella and Malmidea. The Lichenologist 47:9-20.

Cáceres MES, Aptroot A, Mendonça CO, dos Santos LA, Lücking R. 2017. Sprucidea, a further new genus of rain forest lichens in the family Malmideaceae (Ascomycota). The Bryologist 120:202-211.

Clauzade G, Diederich P, Roux C. 1989. Nelikenigintaj fungoj likenlogaj-ilustrita determinlibro. Bulletin de la Société Linnéenne de Provence, Numéro spécial 1:1-142.

Coppins BJ. 1983. A taxonomic study of the lichen genus Micarea in Europe. Bulletin of the British Museum (Natural History), Botany Series 11:17-214.

Culberson CF, Kristinsson H. 1970. A standardized method for the identification of lichen products. Journal of Chromatography 46:85-93.

de los Rios A, Wierzchos J, Ascaso C. 2002. Infection mechanisms of lichenicolous fungi studied by various microscopic techniques. Bibliotheca Lichenologica 82:153-161.

Diederich P. 1997. Lichenicolous fungi in the tropics. Bibliotheca Lichenologica 68:215-221.

Diederich P, Ertz D, Lawrey JD, Sikaroodi M, Untereiner WA. 2013. Molecular data place the hyphomycetous lichenicolous genus Sclerococcum close to Dactylospora (Eurotiomycetes) and S. parmeliae in Cladophialophora (Chaetothyriales). Fungal Diversity 58:61-72.

Diederich P, Lawrey JD, Capdet M, Pereira S, Romero AI, Etayo J, Flakus A, Sikaroodi M, Ertz D. 2014. New lichenassociated bulbil-forming species of Cantharellales (Basidiomycetes). The Lichenologist 46:333-347.

Diederich P, Lawrey JD, Ertz D. 2018. The 2018 classification and checklist of lichenicolous fungi, with 2000 non-lichenized, obligately lichenicolous taxa. The Bryologist 12:340-425.

Divakar PK, Crespo A, Wedin M, Leavitt SD, Hawksworth DL, Myllys L, McCune B, Randlane T, Bjerke JW, Ohmura Y, Schmitt I, Boluda CG, Alors D, Roca-Valiente B, Del-Prado R, Ruibal C, Buaruang K, Núñez-Zapata J, Amo de Paz G, Rico VJ, Molina MC, Elix JA, Esslinger TL, Tronstad IKK, Lindgren H, Ertz D, Gueidan C, Saag L, Mark K, Singh G, Dal Grande F, Parnmen S, Beck A, Benatti MN, Blanchon D, Candan M, Clerc P, Goward T, Grube MI, Hodkinson BP, Hur J-S, Kantvilas G, Kirika PM, Lendemer J, Mattsson J-E, Messuti M, Miadlikowska J, Nelsen M, Ohlson JI, Pérez-Ortega S, Saag A, Sipman HJM, Sohrabi M, Thell A, Thor G, Truong C, Yahr R, Upreti DK, Cubas P, Lumbsch HT. 2015. Evolution of complex symbiotic relationships in a morphologically derived family of lichen-forming fungi. New Phytologist 208:12171226.

Ekman S, Andersen HL, Wedin M. 2008. The limitations of ancestral state reconstruction and the evolution of the ascus in the Lecanorales (lichenized Ascomycota). Systematic Biology 57:141-156.

Ertz D, Diederich P. 2015. Dismantling Melaspileaceae: a first phylogenetic study of Buelliella, Hemigrapha, Karschia, Labrocarpon and Melaspilea. Fungal Diversity 71: 141-164. ErtzD, Diederich P, Lawrey JD, Berger F, Freebury CE, Coppins B, Gardiennet A, Hafellner J. 2015. Phylogenetic insights resolve Dacampiaceae (Pleosporales) as polyphyletic: Didymocyrtis (Pleosporales, Phaeosphaeriaceae) with Phomalike anamorphs resurrected and segregated from Polycoccum (Trypetheliales, Polycoccaceae fam. nov.). Fungal Diversity 74:53-89. 
Ertz D, Fischer E, Killmann D, Razafindrahaja T, Sérusiaux E. 2013. Savoronala, a new genus of Malmideaceae (Lecanorales) from Madagascar with stipes producing sporodochia. Mycological Progress 12:645-656.

Ertz D, Heuchert B, Braun U, Freebury CE, Common RS, Diederich P. 2016 Contribution to the phylogeny and taxonomy of the genus Taeniolella, with a focus on lichenicolous taxa. Fungal Biology 120:1416-1447.

Ertz D, Lawrey JD, Common RS, Diederich P. 2014. Molecular data resolve a new order of Arthoniomycetes sister to the primarily lichenized Arthoniales and composed of black yeasts, lichenicolous and rock-inhabiting species. Fungal Diversity 66:113-137.

Etayo J. 2000. Aportación a la flora liquénica de las Islas Canarias. VI. Hongos liquenícolas de La Palma. Bulletin de la Société linnéenne de Provence 51:153-162.

Etayo J. 2002. Aportación al conocimiento de los hongos liquenícolas de Colombia. Bibliotheca Lichenologica 84:1-154.

Etayo J. 2010. Hongos liquenícola de Perú. Bulletin de la Société linnéenne de Provence 61:1-46.

Etayo J. 2017. Hongos liquenícolas de Ecuador. Opera Lilloana 50:1-535.

Etayo J, Flakus A, Kukwa M. 2018. Three new lichenicolous species of the genus Plectocarpon (Ascomycota: Lecanographaceae) discovered in the Bolivian Andes. Phytotaxa 357:275-283.

Etayo J, Flakus A, Kukwa M, Rodriguez-Flakus P. 2013. Lichenochora tertia (Phyllachorales): the third species of the genus growing on Xanthoria elegans. Mycotaxon 123:9-13.

Etayo J, Flakus A, Suija A, Kukwa M. 2015. Macroskyttea parmotrematis gen. et sp. nov. (Helotiales, Leotiomycetes, Ascomycota), a new lichenicolous fungus from Bolivia. Phytotaxa 224:247-257.

Etayo J, Sancho LG. 2008. Hongos liquenícolas del Sur de Sudamérica, especialmente de Isla Navarino (Chile). Bibliotheca Lichenologica 98:1-302.

Flakus A, Etayo J, Kukwa M. 2014. Melaspilea tucumana, a new gall-forming lichenicolous fungus from the tropical Andes in Bolivia. The Lichenologist 46:657-662.

Flakus A, Etayo J, Kukwa M, Rodriguez-Flakus P. 2016. High diversity of lichenicolous fungi in the tropical Andes of Bolivia. In: The 8th IAL Symposium Lichens in Deep Time, August 1-5, 2016, Helsinki, Finland. IAL8 Abstracts. Helsinki, Finland. p. 182.

Farkas E, Flakus A. 2016. Trichonectria calopadiicola sp. nov. (Hypocreales, Ascomycota): the second species of the family Bionectriaceae parasitic on foliicolous lichens discovered in Tanzania. Phytotaxa 278:281-286.

Flakus A, Kukwa M. 2012. New species of lichenicolous fungi from Bolivia. The Lichenologist 44:469-477.

Frisch A, Thor G, Ertz D, Grube M. 2014. The arthonialean challenge: restructuring Arthoniaceae. Taxon 63:727-744

Grube M, Matzer M. 1997. Taxonomic concepts of lichenicolous Arthonia species. Bibliotheca Lichenologica 68:1-17.

Gumboski EL, Eliasaro S. 2011. Checklist of lichenized fungi of Santa Catarina State (Brazil). Mycotaxon 115: 1-45. [cited 2018 Sep 21]. Available from: http://www.myco taxon.com//resources/checklists/Gumboski-v115-checklist. pdf
Hafellner J. 1982. Studien über lichenicole Pilze und Flechten I. Die Gattung Pleoscutula Vouaux. Herzogia 6:289-298.

Hafellner J. 1984. Studien in Richtung einer natürlicheren Gliederung der Sammelfamilien Lecanoraceae und Lecideaceae. Beiheft zur Nova Hedwigia 79:241-371.

Hafellner J. 1987. Studien über lichenicole Pilze und Flechten V. Über die Gattung Phacopsis Tul. emend. Körber (Lecanorales). Herzogia 7:343-352.

Halıcı MG, Akata I, Kocakaya M. 2010. New records of lichenicolous and lichenized fungi from Turkey. Mycotaxon 114:311-314.

Hawksworth DL. 1991. The fungal dimension of biodiversity: magnitude, significance, and conservation. Mycological Research 95:641-655.

Hawksworth DL. 1993. The tropical fungal biota: census, pertinence, prophylaxis, and prognosis. In: Isaac $S$, Frankland JC, Watling R, Whalley AJS, eds. Aspects of tropical mycology. Cambridge, UK: Cambridge University Press. p. 265-293.

Hawksworth DL. 2001. The magnitude of fungal diversity: the 1.5 million species estimate revisited. Mycological Research 105:1422-1432.

Hawksworth DL. 2003. The lichenicolous fungi of Great Britain and Ireland: an overview and annotated checklist. The Lichenologist 35:191-232.

Hawksworth DL. 2012. Global species numbers of fungi: are tropical studies and molecular approaches contributing to a more robust estimate? Biodiversity and Conservation 21:2425-2433.

Hawksworth DL, Esslinger TL. 1993. Haleomyces oropogonicola, a new pyrenocarpous lichenicolous genus and species on Oropogon lopezii in the Neotropics. The Bryologist 96:349-354.

Hertel H. 1983. Über einige aus Lecidea und Melanolecia (Ascomycetes lichenisati) auszuschliessende Arten. Mitteilungen der Botanischen Staatssammlung München 19:441-447.

Holien H, Palice Z, Björk CR, Goward T, Spribille T. 2016. Lecidea coriacea sp. nov., a lichen species from oldgrowth boreal and montane forests in Europe and North America. Herzogia 29:412-420.

Kalb K, Rivas Plata E, Lücking R, Lumbsch HT. 2011. The phylogenetic position of Malmidea, a new genus for the Lecidea piperis- and Lecanora granifera-groups (Lecanorales, Malmideaceae), inferred from nuclear and mtchondrial ribosomal DNA sequences, with special reference to Thai species. Bibliotheca Lichenologica 106:143168.

Katoh K, Kuma K, Toh H, Miyata T. 2005 MAFFT version 5: improvement in accuracy of multiple sequence alignment. Nucleic Acids Research 33:511-518.

Kilias R. 1981. Revision gesteinsbewohnender Sippen der Flechtengattung Catillaria Massal. in Europa. Herzogia 5:209-448.

Kistenich S, Timdal E, Bendiksby M, Ekman S. 2018. Molecular systematics and character evolution in the lichen family Ramalinaceae (Ascomycota: Lecanorales). Taxon 67:871-904.

Knoph J-G, Rambold G, Triebel D, Kainz C. 2004. Carbonea. In: Nash TH III, Ryan BD, Diederich P, Gries C, Bungartz $\mathrm{F}$, eds. Lichen flora of the greater Sonoran desert region. 
Vol. 2. Tempe, Arizona: Lichens Unlimited, Arizona State University. p. 54-55.

Kraichak E, Huang J-P, Nelsen M, Leavitt SD, Lumbsch HT. 2018. A revised classification of orders and families in the two major subclasses of Lecanoromycetes (Ascomycota) based on a temporal approach. Botanical Journal of the Linnean Society 188:233-249.

Kukwa M, Zwolicki A. 2001. Contribution to the flora of lichenized Ascomycotina of the Czywczyn Mts. (Eastern Carpathians, Ukraine) V. Cladina, Cladonia and their lichenicolous fungi. In: Zavarzin AA, Petrova OV, Sonina AV, Tarasova VN, eds. Proceeding of the First Lichenological Field Meeting, Apatity, 6-12 Agust 2000. Petrozavodsk, Russia. p. 301-305.

Lanfear R, Calcott B, Ho SYW, Guidon S. 2012. PartitionFinder: combined selection of partitioning schemes and substitution models for phylogenetic analyses. Molecular Biology and Evolution 29:1695-1701.

Lanfear R, Frandsen PB, Wright AM, Senfeld T, Calcott B. 2016. PartitionFinder 2: new methods for selecting partitioned models of evolution for molecular and morphological phylogenetic analyses. Molecular Biology and Evolution 34:772-773.

Lawrey JD, Diederich P. 2003. Lichenicolous fungi: interactions, evolution and biodiversity. The Bryologist 106:80-120.

Lawrey JD, Binder M, Diederich P, Molina MC, Sikaroodi M, Ertz D. 2007. Phylogenetic diversity of lichen-associated homobasidiomycetes. Molecular Phylogenetics and Evolution 44:778-789.

Lawrey JD, Diederich P, Nelsen MP, Freebury C, Van den Broeck D, Sikaroodi M, Ertz D. 2012. Phylogenetic placement of lichenicolous Phoma species in the Phaeosphaeriaceae (Pleosporales, Dothideomycetes). Fungal Diversity 55:195213.

Lawrey JD, Zimmermann E, Sikaroodi M, Diederich P. 2016. Phylogenetic diversity of bulbil-forming lichenicolous fungi in Cantharellales including a new genus and species. The Bryologist 119:341-349.

Liu XZ, Wang QM, Göker M, Groenewald M, Kachalkin AV, Lumbsch HT, Millanes AM, Wedin M, Yurkov AM, Boekhout T, Bai FY. 2016. Towards an integrated phylogenetic classification of the Tremellomycetes. Studies in Mycology 81:85-147.

Miadlikowska J, Kauff F, Högnabba F, Oliver JC, Molnár K, Fraker E, Gaya E, Hafellner J, Hofstetter V, Gueidan C, Otálora MAG, Hodkinson B, Kukwa M, Lücking R, Björk C, Sipman HJM, Burgaz AR, Thell A, Passo A, Myllys L, Goward T, Fernández-Brime S, Hestmark G, Lendemer J, Lumbsch HT, Schmull M, Schoch CL, Sérusiaux E, Maddison DR, Arnold AE, Lutzoni F, Stenroos S. 2014. A multigene phylogenetic synthesis for the class Lecanoromycetes (Ascomycota): 1307 fungi representing 1139 infrageneric taxa, 317 genera and 66 families. Molecular Phylogenetics and Evolution 79:132-168.

Millanes AM, Diederich P, Ekman S, Wedin M. 2011. Phylogeny and character evolution in the jelly fungi (Tremellomycetes, Basidiomycota, Fungi). Molecular Phylogenetics and Evolution 61:12-28.

Miller MA, Pfeiffer W, Schwartz T. 2010. Creating the CIPRES Science Gateway for inference of large phylogenetic trees. In: Proceedings of the Gateway Computing
Environments Workshop (GCE), 14 Nov 2010, New Orleans, LA: Curran Associates, Inc. p. 1-8.

Muggia L, Fleischhacker A, Kopun T, Grube M. 2016. Extremotolerant fungi from alpine rock lichens and their phylogenetic relationships. Fungal Diversity 76:119-142.

Muggia L, Kopun T, Ertz D. 2015. Phylogenetic placement of the lichenicolous, anamorphic genus Lichenodiplis and its connection to Muellerella-like teleomorphs. Fungal Biology 119:1115-1128.

Muggia L, Mancinelli R, Tønsberg T, Jablonska A, Kukwa M, Palice Z. 2017. Molecular analyses uncover the phylogenetic placement of the lichenized hyphomycetous genus Cheiromycina. Mycologia 109:588-600.

Müller J. 1891. Lichenes Schenckiani a cl. Dr. H. Schenck, Bonnensi, in Brasiliae orientalis prov. Santa Catharina, Parana, Rio de Janeiro, Minas Geraes et Pernambuco lecti. Hedwigia 30:219-234.

Nylander W. 1887. Addenda nova ad Lichenographiam Europaeam. Continuatio quadragesima septima. Flora 70:129-136.

Oksanen J, Blanchet FG, Kindt R, Legendre P and others. 2013. Vegan: community ecology package. [cited $2016 \mathrm{Feb}$ 15]. Available from: http://cran.r-project.org/web/ packages/vegan/index

Olivier H 1905. Les principaux parasites de nos lichens français. Bulletin de l'Académie Internationale de Géographie Botanique 15:273-284.

Orange A, James PW, White FJ. 2001. Microchemical methods for the identification of lichens. London: British Lichen Society. $101 \mathrm{p}$.

Page RDM. 1996. TreeView: an application to display phylogenetic trees on personal computers, Bioinformatics 12:357-358

Palice Z, Malíček J, Peksa O, Vondrák J. 2018. New remarkable records and range extensions in the central European lichen biota. Herzogia 31:518-534.

Penn O, Privman E, Ashkenazy H, Landan G, Graur D, Pupko T. 2010. GUIDANCE: a web server for assessing alignment confidence scores. Nucleic Acids Research 38:W23-W28.

Pérez-Ortega S, Garrido-Benavent I, de Los Ríos A. 2015. Austrostigmidium, a new austral genus of lichenicolous fungi close to rock-inhabiting meristematic fungi in Teratosphaeriaceae. The Lichenologist 47:143-156.

Pérez-Ortega S, Suija A, Crespo A, de Los Ríos A. 2014. Lichenicolous fungi of the genus Abrothallus (Dothideomycetes: Abrothallales ordo nov.) are sister to the predominantly aquatic Jahnulales. Fungal Diversity 64:295-304.

Peršoh D, Rambold G. 2002. Phacopsis-a lichenicolous genus of the family Parmeliaceae Mycological Progress 1:43-55.

Pino-Bodas R, Zhurbenko MP, Stenroos S. 2017. Phylogenetic placement within Lecanoromycetes of lichenicolous fungi associated with Cladonia and some other genera. Persoonia 39:91-117.

Pirogov M, Chepelevska N, Vondrák J. 2014. Carbonea in Ukraine. Studia Biologica 8:137-148.

Printzen C. 1995. Die Flechtengattung Biatora in Europa. Bibliotheca Lichenologica 60:1-275.

R Core Team. 2016. R: a language and environment for statistical computing. Vienna, Austria: R Foundation for Statistical Computing. [cited 2016 Feb 15]. Available from: https://www.R-project.org/ 
Rambold G. 1993. Further species of the genus Tephromela (Lecanorales). Sendtnera 1:281-288.

Rambold G, Triebel D. 1992. The inter-lecanoralean associations. Bibliotheca Lichenologica 48:1-201.

Rehner SA, Samuels GJ. 1994. Taxonomy and phylogeny of Gliocladium analysed from nuclear large subunit ribosomal DNA sequences. Mycological Research 98:625-634.

Rodriguez-Flakus P, Printzen C. 2014. Palicella, a new genus of lichenized fungi and its phylogenetic position within Lecanoraceae. The Lichenologist 46:535-552.

Ronquist F, Teslenko M, Van der Mark P, Ayres D, Darling A, Höhna S, Larget B, Liu L, Suchard MA, Huelsenbeck JP. 2012. MrBayes 3.2: efficient Bayesian phylogenetic inference and model choice across a large model space. Systematic Biology 61:539-542.

RStudio Team. 2015. RStudio: integrated development for $\mathrm{R}$ [computer software version 0.98.1074]. Boston, Massachusetts: RStudio, Inc. [cited 2016 Feb 15]. Available from: http://www.rstudio.com/

Ruibal C, Millanes AM, Hawksworth DL. 2011. Molecular phylogenetic studies on the lichenicolous Xanthoriicola physciae reveal Antarctic rock-inhabiting fungi and Piedraia species among closest relatives in the Teratosphaeriaceae. IMA Fungus 2:97-103.

Saccardo PA, Saccardo D. 1906. Sylloge fungorum omnium hucusque cognitorum. Vol. XVIII. Supplementum universale Pars VII, Patavii. I-VII + 838 p.

Sikaroodi M, Lawrey JD, Hawksworth DL, DePriest PT. 2001. The phylogenetic position of selected lichenicolous fungi: Hobsonia, Illosporium, and Marchandiomyces. Mycological Research 105:453-460.

Sodamuk M, Boonpragob K, Mongkolsuk P, Tehler A, Leavitt SD, Lumbsch HT. 2017. Kalbionora paleotropica, a new genus and species from coastal forest in South Asia and Australia (Malmideaceae, Ascomycota). MycoKeys 22:15-25.

Stamatakis A. 2006. RAxML-VI-HPC: maximum likelihood based phylogenetic analyses with thousands of taxa and mixed models. Bioinformatics 22:2688-2690.

Stenroos S, Hyvönen J, Myllys L., Thell A., Ahti T. 2002. Phylogeny of the genus Cladonia s.lat. (Cladoniaceae, Ascomycetes) inferred from molecular, morphological, and chemical data. Cladistics 18: 237278.

Suija A, de los Ríos A, Pérez-Ortega S. 2015a. A molecular reappraisal of Abrothallus species growing on lichens of the order Peltigerales. Phytotaxa 195:201-226.

Suija A, Ertz D, Lawrey JD, Diederich P. 2015b. Multiple origin of the lichenicolous life habit in Helotiales, based on nuclear ribosomal sequences. Fungal Diversity 70:55-72.
Suija A, Kaasalainen U, Kirika PM, Rikkinen J. 2018. Taitaia, a novel lichenicolous fungus in tropical montane forests in Kenya (East Africa). The Lichenologist 50:173-184.

Timdal E. 1992['1991']. A monograph of the genus Toninia (Lecideaceae, Ascomycetes). Opera Botanica 110:1-137.

Trakunyingcharoen T, Lombard L, Groenewald JZ, Cheewangkoon R, Toanun C, Alfenas AC, Crous PW. 2014. Mycoparasitic species of Sphaerellopsis, and allied lichenicolous and other genera. IMA Fungus 5:391-414.

Triebel D, Rambold G, Elix JA. 1995. A conspectus of the genus Phacopsis (Lecanorales). The Bryologist 98:71-83.

Triebel D, Wedin M, Rambold G. 1997. The genus Scutula (lichenicolous ascomycetes, Lecanorales): species on the Peltigera canina and $P$. horizontalis groups. Symbolae Botanicae Upsalienses 32:323-337.

Van den Boom PPG, Ertz D. 2014. A new species of Micarea (Pilocarpaceae) from Madeira growing on Usnea. The Lichenologist 46:295-301.

Vilgalys R, Hester M. 1990. Rapid genetic identification and mapping of enzymatically amplified ribosomal DNA from several Cryptococcus species. Journal of Bacteriology 172:4238-4246.

Wedin M, Ihlen PG, Triebel D. 2007. Scutula tuberculosa, the correct name of the Scutula growing on Solorina spp., with a key to Scutula s. str. in the Northern Hemisphere. The Lichenologist 39:329-333.

Zhurbenko MP. 2001. Lichenicolous fungi from Murmansk region of Russia. Mikologiya Fitopatologiya 35:34-40.

Zhurbenko MP, Alstrup V. 2004. Lichenicolous fungi on Cladonia mainly from the Arctic. Symbolae Botanicae Upsalienses 34:477-499.

Zhurbenko MP, Pino-Bodas R. 2017. A revision of lichenicolous fungi growing on Cladonia, mainly from the Northern Hemisphere, with a worldwide key to the known species. Opuscula Philolichenum 16:188-266.

Zhurbenko MP, Pospelova EB. 2001. Lichenes ac fungi lichenophili in vicinitate lacus Syrutaturku (reservatum Taymyricum, Taymyr Centralis). Novitates Systematicae Plantarum non Vascularium (Petropolis) 34:134-139.

Zhurbenko MP, Santesson R. 1996. Lichenicolous fungi from the Russian Arctic. Herzogia 12:147-161.

Zoller S, Scheidegger C, Sperisen C. 1999. PCR primers for the amplification of mitochondrial small subunit ribosomal DNA of lichen-forming ascomycetes. The Lichenologist 31:511-516. 